\title{
T cell-recruiting triplebody 19-3-19 mediates serial lysis of malignant B-lymphoid cells by a single $\mathrm{T}$ cell
}

\author{
Claudia C. Roskopf ${ }^{1}$, Christian B. Schiller ${ }^{2}$, Todd A. Braciak ${ }^{1}$, Sebastian Kobold ${ }^{3}$, \\ Ingo A. Schubert ${ }^{4}$, Georg H. Fey ${ }^{4}$, Karl-Peter Hopfner ${ }^{2}$, Fuat S. Oduncu ${ }^{1}$ \\ 1 Klinikum der Universität München, Medizinische Klinik und Poliklinik IV, Haematology/Oncology, Munich, Germany \\ 2 Ludwig-Maximilians-Universität München, Department of Biochemistry/Gene Center, Munich, Germany \\ ${ }^{3}$ Klinikum der Universität München, Medizinische Klinik und Poliklinik IV, Division of Clinical Pharmacology, Munich, Germany \\ ${ }^{4}$ Friedrich-Alexander-Universität Erlangen-Nürnberg, Department of Biology, Erlangen, Germany
}

Correspondence to:

Claudia C. Roskopf, e-mail: Claudia.Roskopf@med.uni-muenchen.de

Key Words: immunotherapy, triplebody, cytolytic T cells, antibody-dependent cellular cytotoxicity, leukemia

Received: June 06, 2014

Accepted: July 15, 2014

Published: July 23, 2014

\section{ABSTRACT}

Triplebody 19-3-19, an antibody-derived protein, carries three single chain fragment variable domains in tandem in a single polypeptide chain. 19-3-19 binds CD19-bearing lymphoid cells via its two distal domains and primary $T$ cells via its CD3-targeting central domain in an antigen-specific manner. Here, malignant B-lymphoid cell lines and primary cells from patients with B cell malignancies were used as targets in cytotoxicity tests with pre-stimulated allogeneic $\mathbf{T}$ cells as effectors. 19-3-19 mediated up to $95 \%$ specific lysis of CD19-positive tumor cells and, at picomolar $\mathrm{EC}_{50}$ doses, had similar cytolytic potency as the clinically successful agent Blinatumomab ${ }^{\mathrm{TM}}$. 19-3-19 activated resting $\mathrm{T}$ cells from healthy unrelated donors and mediated specific lysis of both autologous and allogeneic CD19-positive cells. 19-3-19 led to the elimination of $70 \%$ of CD19-positive target cells even with resting $\mathrm{T}$ cells as effectors at an effector-to-target cell ratio of $1: 10$. The molecule is therefore capable of mediating serial lysis of target cells by a single $\mathrm{T}$ cell. These results highlight that central domains capable of engaging different immune effectors can be incorporated into the triplebody format to provide more individualized therapy tailored to a patient's specific immune status.

\section{BACKGROUND}

Therapeutic antibodies such as MabThera $^{\circledR}$, Herceptin $^{\circledR}$ and Avastin $^{\circledR}$ are potent and successful tools in the fight against cancer.[1] Recombinant proteins derived from conventional antibodies have been designed to increase tumor cell selectivity and deeper penetration into tumor tissues, and to exploit the patients' innate defense mechanisms against their disease. $[2,3]$ Several of the new antibody-derived agents including immunoligands[4-6], diabodies, bispecific (bs) scFvs[7, 8], single chain triplebodies[9-12] and, most recently, a modular targeting system[13] - are based on single chain variable fragment ( $\mathrm{scFv}$ ) building blocks and lack an $\mathrm{Fc}$ region. While maintaining target specificity, the $\mathrm{scFv}$-based agents are expected to reach deeper tissue penetration due to their reduced molecular mass. $[14,15]$ The lack of an $\mathrm{Fc}$ region is also thought to reduce undesired side effects, which are caused by binding to $\mathrm{Fc}$ receptors that are exposed on cells other than the desired cytolytic effectors.[2,3]

Despite the lack of an $\mathrm{Fc}$ region, scFv-based agents have effective mechanisms of action. The anti-Her2/ anti-Her3 bsscFv MM-111[16], for example, relies on simultaneous blockage of two different growth factor receptors and the cooperative inhibition of essential growth-promoting and anti-apoptotic downstream signals. Other mechanisms of action include the induction of apoptosis via surface receptors such as FasR (CD95)[17] and target-specific delivery of a toxin or radioisotope cargo by internalization (receptor-mediated endocytosis). Another option is the engagement of autologous effector 
cells, such as natural killer (NK)-cells and cytotoxic $\mathrm{T}$ lymphocytes (CTLs), for cytolysis.[2, 3]

NK cells can, for example, be recruited by the TandAb ${ }^{\text {TM }}$ AFM-13 (CD30-CD16; Affimed) designed for the treatment of Hodgkin Lymphoma.[18] Examples for T cell recruitment via scFv-based agents are the bispecific $\mathrm{T}$ cell engagers (BiTEs; Micromet/Amgen). Antibodyderivatives in the BiTE-format coat their tumor cell targets and engage effector memory $\mathrm{T}$ cells independent of their MHC : peptide specificity via the $\mathrm{CD} 3 \varepsilon$ chain of the $\mathrm{T}$ cell receptor-CD3 (TCR/CD3) complex.[7] Coupling between $\mathrm{T}$ cell and tumor cell leads to the formation of a cytolytic synapse and degranulation of the $\mathrm{T}$ cell. $[7,19]$ Moreover, the engagement of effector memory $T$ cells via BiTEs leads to their proliferation and thus to an expansion of the effector cell population that is available for tumor cell lysis during the course of the treatment.[20-22] The CD19-specific BiTE Blinatumomab ${ }^{\mathrm{TM}}$ has shown impressive success in clinical studies with patients suffering from acute and chronic B cell malignancies.[20, 22-24] Other BiTEs targeting CD33 (CD33-CD3; AMG330) [25, 26], EpCAM (MT110; EpCAM-CD3)[27-29] and CEA (MT111; CEA-CD3)[30, 31], respectively, have produced promising results in recent pre-clinical studies and ongoing clinical trials.

However, despite their success, these bispecific agents still face limitations, which are difficult to overcome with this molecular format, including limitations in tumor cell specificity and "plasma retention time" ("plasma half-life").[22, 23] The drawback in specificity is due to the fact, that the BiTE-format is monospecific and monovalent for the tumor cell, recognizing only one target antigen. While mono-targeting has been successful in several applications, it may not confer sufficient specificity for cancer cells and sufficient discrimination between cancer and healthy cells in many other cases. Given that spontaneously arising cancer cells share many antigens with healthy cells, and that many of the most promising targets, such as growth factor receptors (e.g. EGFreceptor) and cell adhesion molecules (e.g. EpCAM) are not tumor-specific, this situation will occur. Therefore, monospecific agents have often caused side effects that are difficult to manage. In addition, under therapy with monospecific agents, escape mutants of tumor cells can emerge, which have lost the surface expression of the corresponding target antigen and have become resistant to treatment.[32] Dual-targeting agents, which address two different target antigens on the same cancer cell, may be capable of overcoming some of these limitations. Also, most BiTEs have a molecular mass below $65 \mathrm{kDa}$ and thus below the kidney excretion limit, which results in a plasma half-life in the range of approximately 1 hour.[33] This shortcoming can be addressed by agents with a higher molecular mass and by extending the half-life by PEGylation, by fusion to human serum albumin (HSA) domains carrying a binding site for the FcRn shuttling receptor, or antibodies and antibody fragments with specificity for HSA.[34]

To take advantage of these added capabilities offered by multispecific scFv-based agents, the molecular format of "single chain triplebodies" ("triplebodies") has been developed by our group. A triplebody is composed of three scFvs connected via flexible (Gly $\left.{ }_{4} \mathrm{Ser}\right)_{4}$ linkers, which results in a maximum computed distance of $20 \mathrm{~nm}$ between the two distal binding moieties[35] and a molecular mass of 85 to $95 \mathrm{kDa}$.[36] This mass exceeds the threshold for first-pass kidney excretion and consequently, triplebodies have a prolonged plasma half-life of approximately $4 \mathrm{hrs}$ in mice. This corresponds to approx. 1 day in humans by allometric scaling.[9] Triplebodies can be designed to recruit different classes of effector cells via their central $\mathrm{scFv}$, which is specific for an activating surface molecule such as CD16 on NK cells and macrophages[9, 10, 36], CD89 on polymorphonuclear granulocytes (PMNs)[37], or CD64 on macrophages and cytokine-stimulated PMNs.[3] The two distal binding moieties of the triplebody are capable of either monospecific bivalent targeting (example: 19-16-19)[9] or bispecific bivalent targeting ("dual-targeting") of two different target antigens on the same cancer cell (examples: 123-16-33[36], 33-16-19[10] and HLA-DR-16-19[11]). Dual-targeting triplebodies have been shown to achieve preferential binding[4] and to mediate preferential lysis[38] of double-positive over single-positive target cells by cytolytic effectors in a mixed environment. They even permitted preferential effector-cell mediated lysis of the double-positive cells when the single-positive cells were present in an up to 20-fold numerical excess. For some target antigen combinations the dual-targeting approach may not be successful, because individual target affinities, antigen surface densities and the genetically and epigenetically determined susceptibility of the target cell to effector cellmediated lysis need to cooperate for enhanced potency. [28] Nevertheless, dual-targeting triplebodies have been successful in preclinical studies for a number of different combinations of target antigens, and therefore this concept deserves further exploration.

The ability of triplebodies to recruit $T$ cells as effectors is unaddressed so far and it is uncertain whether the fine structure of an immunological synapse mediated by a triplebody would be functional, as demonstrated for NK cells. In the present study a single chain triplebody was constructed and tested for the ability to recruit cytotoxic T cells (CTLs) as effectors for the lysis of CD19-positive leukemia cells. As we demonstrate in our current study, the new triplebody anti-CD19/anti-CD3/ anti-CD19 (19-3-19) is capable of activating resting $\mathrm{T}$ cells and of mediating redirected and serial lysis of tumor cells, both of established B-ALL cell lines and of primary cells isolated from the peripheral blood of patients suffering from different types of B cell malignancies. The successful recruitment of effector $\mathrm{T}$ cells via 
19-3-19 indicates that the triplebody platform can be used to recruit an even broader range of effector cells. The thus highlighted ability of the triplebody format to choose an optimally suited effector cell for therapy by adjusting the central trigger $\mathrm{scFv}$ based on a patient's specific cancer type and the availability of these effectors in the tumor tissue increases the range of therapeutic options and may add an additional layer to individualized cancer therapy.

\section{RESULTS}

\section{Design and production of triplebody 19-3-19.}

Triplebody 19-3-19 carries a scFv domain derived from the murine hybridoma antibody OKT3 (directed against human $\mathrm{CD} 3 \varepsilon$ ) in the central position, and CD19specific $\mathrm{scFv}$ domains, targeting the B-lineage antigen CD19, derived from hybridoma $4 \mathrm{G} 7$ as previously described (Fig. 1).[9] In this fusion protein with an N-terminal Strep-tag and a C-terminal His-tag, the CD19specific $\mathrm{scFv}$ components were humanized by CDRgrafting.[39] Triplebody 19-3-19 was expressed both in adherent HEK $293 \mathrm{~T}$ cells and in suspension-adapted HEK 293F cells with yields between 0.9 and $5.1 \mathrm{mg}$ protein/L culture supernatant in different experiments (Table 1). HEK 293F cells permitted cultivation in serum-free medium and efficient purification via Ni-NTA affinity chromatography. The $\mathrm{N}$ - and C-termini were intact and no degradation products were detected (Fig. 2). In addition, two new agents in the Bispecific $\mathrm{T}$ cell Engager (BiTE)-format were produced as controls. One carried our humanized CD19-specific $\mathrm{scFv}$ domain and was designated 19-3 ("Blinatumomab"TM-look-alike"), the other carried scFvs with specificity for Her2/NEU and CD $3 \varepsilon$ and was designated Her2-3. Finally, a control triplebody targeting Her2/NEU (designated Her2-3-Her2) was also produced. Expression of Her2-3-Her2 and Her23 was efficient with yields of 8.5 and $9.2 \mathrm{mg} / \mathrm{L}$ of culture supernatant, respectively (Table 1).

\section{Triplebody 19-3-19 binds specifically both to its target antigens and the trigger protein.}

Both the triplebody 19-3-19 and the BiTE 19-3 bound to primary human $\mathrm{T}$ cells isolated from ex vivo expanded mononuclear cells (Fig. 3A; left), as well as to CD19-positive Nalm-6 cells (a pre-B ALL-derived cell line; Fig. 3A, right), but it did not bind to antigennegative HEK 293F cells (data not shown). The Her2-3Her2 specificity control bound to $T$ cells via the trigger CD $3 \varepsilon$, but not to Her2- and CD3 $\varepsilon$-negative Nalm- 6 cells. At the saturating concentration of $15 \mu \mathrm{g} / \mathrm{mL}$ both the control triplebody Her2-3-Her2 and the 19-3 BiTE showed stronger binding to $\mathrm{T}$ cells than triplebody $19-3-19$, as evidenced by a stronger shift in the mean fluorescence intensity (MFI) of the cell-bound fusion proteins detected by cytofluorimetry (Fig. 3A, left panel). Thus the binding capacity of the $\mathrm{CD} 3 \varepsilon$-specific $\mathrm{scFv}$ domain was affected by its molecular context within a given fusion protein. The difference in binding strength was also reflected in the equilibrium dissociation constants $\left(\mathrm{K}_{\mathrm{D}}\right.$ values $)$ of 19-3-19 and 19-3 for CD3e exposed on primary T cells. The triplebody bound less strongly with an affinity of $53.3 \pm 19 \mathrm{nM}$ compared to $34.7 \pm 14 \mathrm{nM}$ for the BiTE 19-3 (Fig. 3B, left panel), but the difference was not significant. The overall avidity of the triplebody for CD19

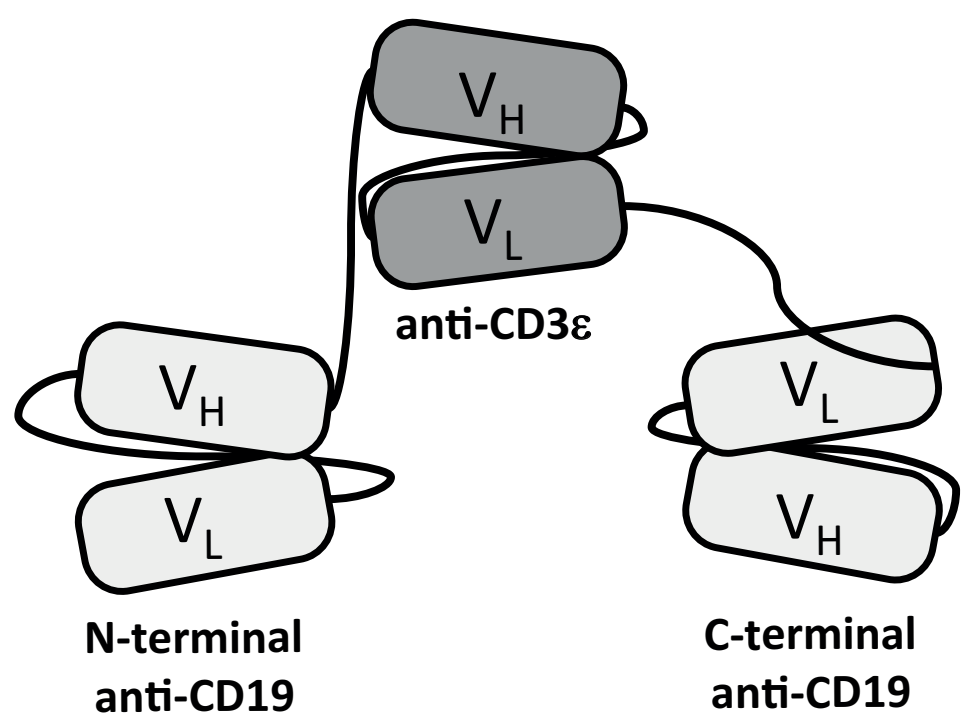

Figure 1: Domain architecture of T cell-recruiting triplebody 19-3-19. Triplebody 19-3-19 binds to the CD3 $\varepsilon$ chain of the TCR/CD3 complex via its central scFv and to two copies of CD19 on the surface of a malignant target cell via its two distal scFvs. The scFvs are connected by flexible $\left(\mathrm{G}_{4} \mathrm{~S}\right)_{4}$-linkers (black lines), which gives the molecule a maximum computed span length (distance between the two distal binding sites) of $20 \mathrm{~nm}$, when the flexible linkers are fully extended. 

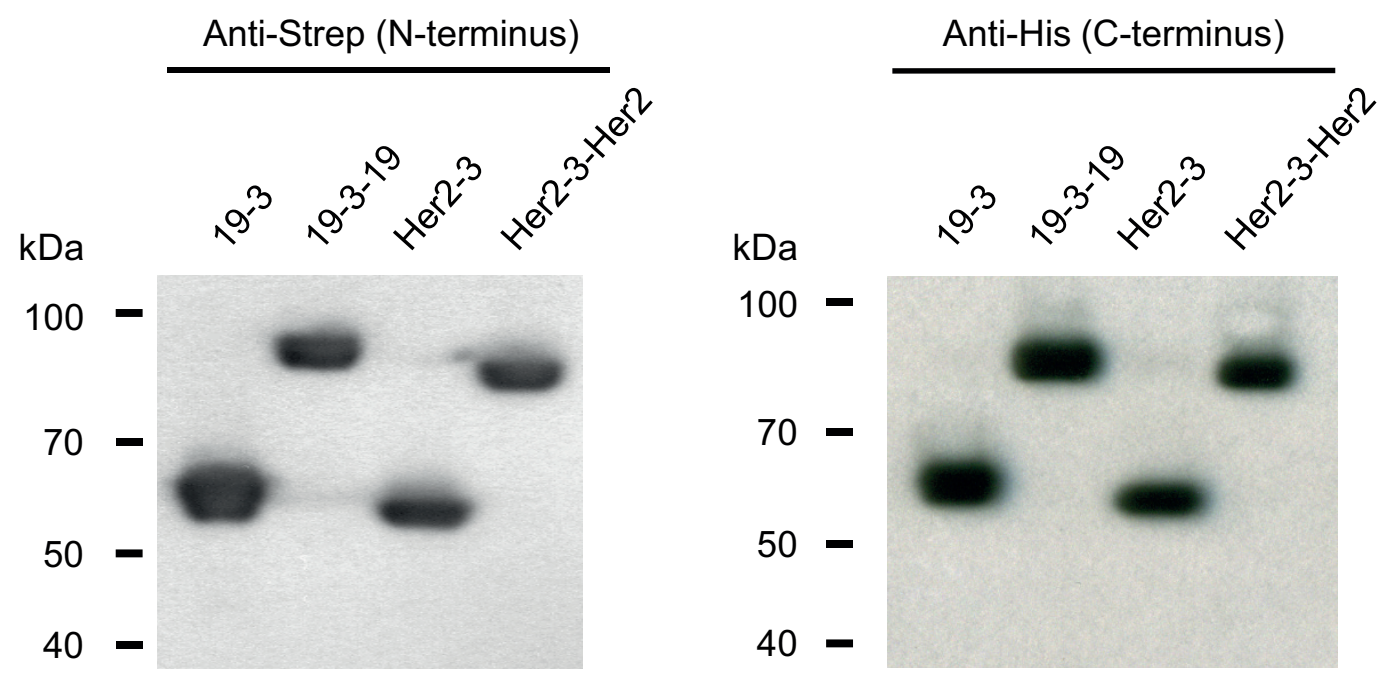

Figure 2: N- and C-termini of triplebody 19-3-19 and control proteins 19-3, Her2-3 and Her2-3-Her2 were intact. The fusion proteins carried N-terminal Strep and C-terminal hexa-histidine tags. Western blot analysis with antibodies reacting with the Strepand His-tags, respectively, revealed that the fusion proteins carried intact $\mathrm{N}$ - and $\mathrm{C}$-termini and provided no indication for incomplete synthesis or proteolytic degradation.

Table 1. Molecular masses and yields of $T$ cell-engaging triplebodies and bispecific scFvs. Proteins were expressed and purified as described in the Methods section. Buffer conditions were chosen to minimize protein aggregation. Proteins were concentrated to $150-300 \mathrm{ng} / \mu \mathrm{L}$ in the storage buffer by centrifugation, using centrifugal filters with a molecular weight cut-off (MWCO) of $50 \mathrm{kDa}$ for the triplebodies and $10 \mathrm{kDa}$ for bispecific scFvs. Theoretical molecular masses were computed from the known amino acid sequence composition of the molecules.

\begin{tabular}{|c|c|c|c|}
\hline Protein & $\begin{array}{c}\text { Computed Mass } \\
{[\mathrm{kDa}]}\end{array}$ & $\begin{array}{c}\text { Yield }[\mathrm{mg} / \mathrm{L}] \\
(293 \mathrm{~F} \text { cells })\end{array}$ & Storage Buffer \\
\hline anti[CD19-CD3] & 60.7 & $0.9-4.8$ & \multirow{4}{*}{$\begin{array}{l}\text { 20mM L-Histidin } \\
300 \mathrm{mM} \mathrm{NaCl} \\
\text { 100mM D-Trehalose } \\
5 \mathrm{mM} \text { EDTA } \\
10 \% \text { Glycerol } \\
\text { pH } 6.5\end{array}$} \\
\hline anti[CD19-CD3-CD19] & 89.9 & $0.9-5.1$ & \\
\hline anti[Her2-CD3] & 59.5 & $1.8-9.2$ & \\
\hline anti[Her2-CD3-Her2] & 87.2 & $6.0-8.5$ & \\
\hline
\end{tabular}

on the surface of SEM (pro-B ALL) cells was $14.7 \pm 2$ $\mathrm{nM}$. Thus, the binding-strength of the triplebody for CD19 was approximately two-fold greater than the monovalent affinity of the CD19-specific scFv-domain carried in the control 19-3 with a $K_{D}$ value of $28.4 \pm 1 \mathrm{nM}$ (Fig. $3 \mathrm{~B}$, right panel). These numerical values indicate that the two CD19-specific scFv domains of triplebody 193-19 contributed to the overall avidity of this protein in an additive rather than a synergistic manner, which was previously reported for the triplebody 19-16-19.[9] This observation suggests that the detailed spatial arrangement assumed by the two CD19-specific scFvs in a triplebody, which mediate the association with a target cell, is different between an NK- and a T cell-recruiting agent. The increase in avidity for CD19 on living cells observed for the triplebody relative to the BiTE is also evidence that both CD19-binding sites of the triplebody can simultaneously bind one copy each of CD19 on the same target cell.

\section{Triplebody 19-3-19 mediates specific target cell lysis in combination with effector $\mathbf{T}$ cells.}

To investigate whether the formation of a cytolytically productive synapse between an effector $\mathrm{T}$ cell and its tumor cell target can be mediated by triplebody 19-3-19, redirected lysis (RDL) assays were performed. For this purpose, a panel of CD19-positive leukemia- and lymphoma-derived cell lines representing different types of B cell-malignancies were used as targets with a 

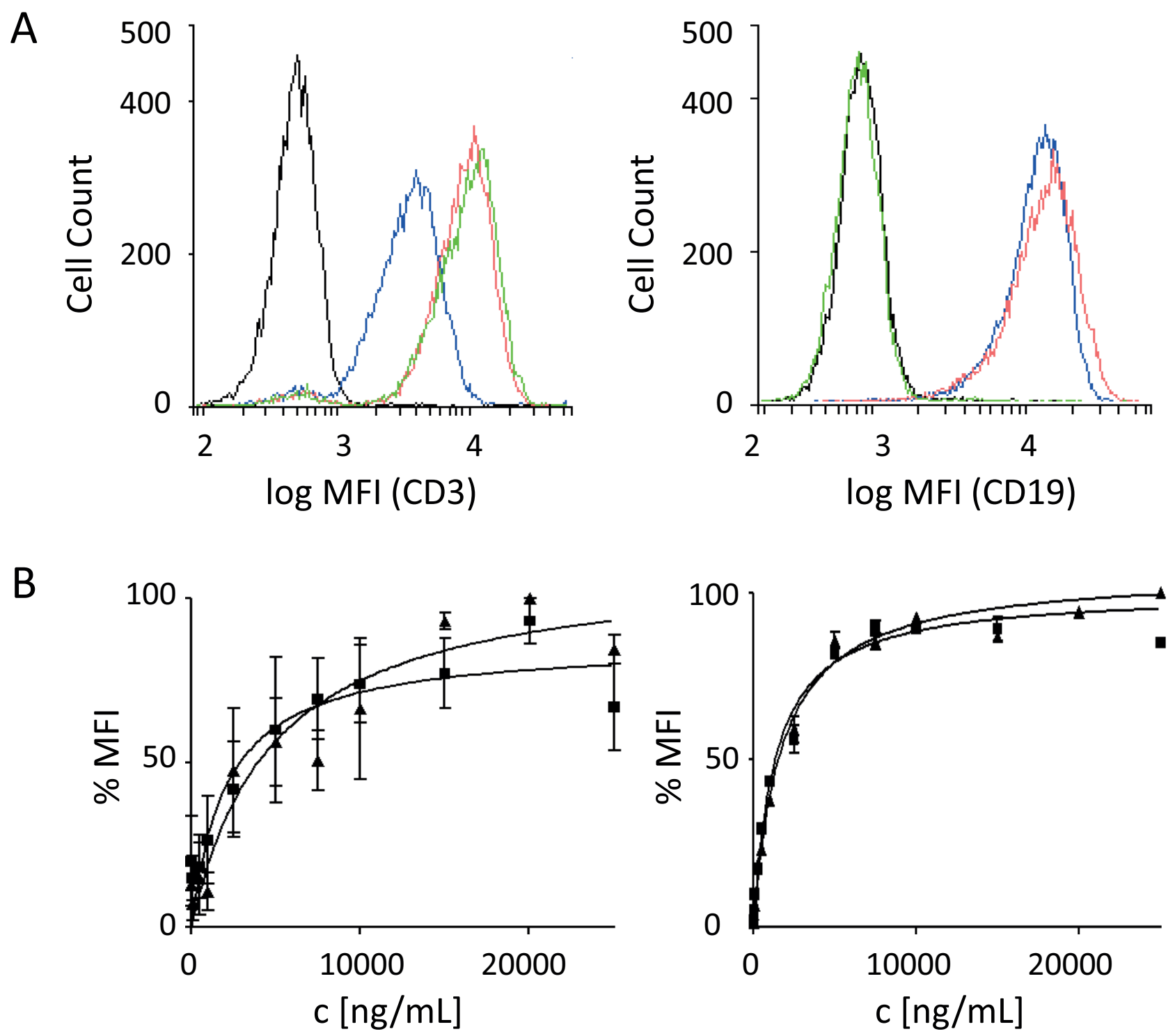

Figure 3: Binding specificities of the scFv components of triplebody 19-3-19. Target specificity of the 19-3 BiTE protein and triplebody 19-3-19 was examined by flow cytometry as described.[53] Molecules bound to the surface of single-positive target cells were detected with a secondary anti-His $\mathrm{mAb}$ and a Phycoerythrin (PE)-conjugated tertiary goat-anti-mouse IgG mAb. (A) Shift in mean fluorescence intensity (MFI) produced by binding to primary T cells (left), and Nalm-6 cells (right) at a saturating concentration of $15 \mu \mathrm{g} / \mathrm{mL}$ of either the BiTE or the triplebody. Black: isotype control; blue: triplebody 19-3-19; red: 19-3 BiTE; green: control triplebody Her2-3-Her2. MFIs are given as logarithms to the base of 10. (B) Determination of equilibrium dissociation constants $\mathrm{K}_{\mathrm{D}}$ of 19-3 and the triplebody 19-3-19 for CD3 on primary T cells $(\mathrm{n}=4)$, and for CD19 on SEM cells $(\mathrm{n}=7)$. Error bars indicate standard error of the mean (SEM). The dissociation constants for CD3 were $34.7 \pm 14 \mathrm{nM}$ and $53.3 \pm 19 \mathrm{nM}$ for the BiTE and the triplebody, respectively. The dissociation constants for CD19 were 28.4 $\pm 1 \mathrm{nM}$ for 19-3 and 14.7 $\pm 2 \mathrm{nM}$ for triplebody 19-3-19, where the latter value refers to the overall (bivalent) avidity of the entire molecule, not to the monovalent affinity of the individual CD19-specific scFvs.

T cell : target cell ratio of $6: 1$. Triplebody $19-3-19$ or control proteins 19-3 and Her2-3-Her2 were added at different concentrations and after a $3 \mathrm{hr}$ reaction time target cell death was measured by Calcein release.[11, 38] 19-3-19 and 19-3 produced significant specific lysis of CD19positive target cells in a dose-dependent manner (Fig. 4a). However, even at the highest concentration of $10 \mathrm{nM}$, the specificity control triplebody Her2-3-Her2 did not produce any significant specific lysis ( $3.5 \pm 5 \%$ background). This result is in accordance with an earlier report[40] describing that the sole binding of a BiTE protein to $\mathrm{CD} 3 \varepsilon$ on the T cell in the absence of binding to the target cell was not sufficient to induce bystander lysis of target cells by the T cells.

Lysis of SEM cells occurred with a sigmoidal dose-response with a maximum specific lysis of $89.8 \pm 9 \%$ after $3 \mathrm{hrs}$ (mean of 4 experiments) and an EC50-value of 5.5 pM (95\% CI: 3-9 pM). Dose-responses 
A

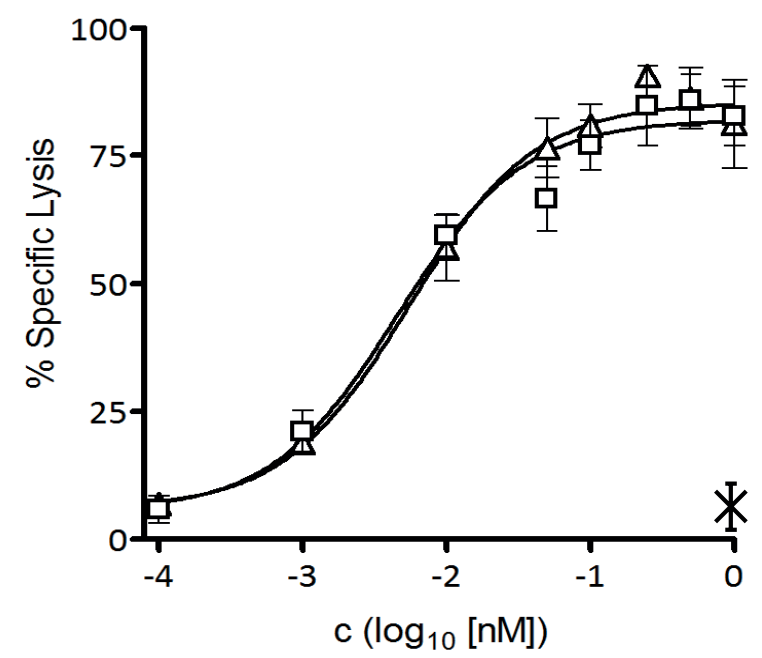

B

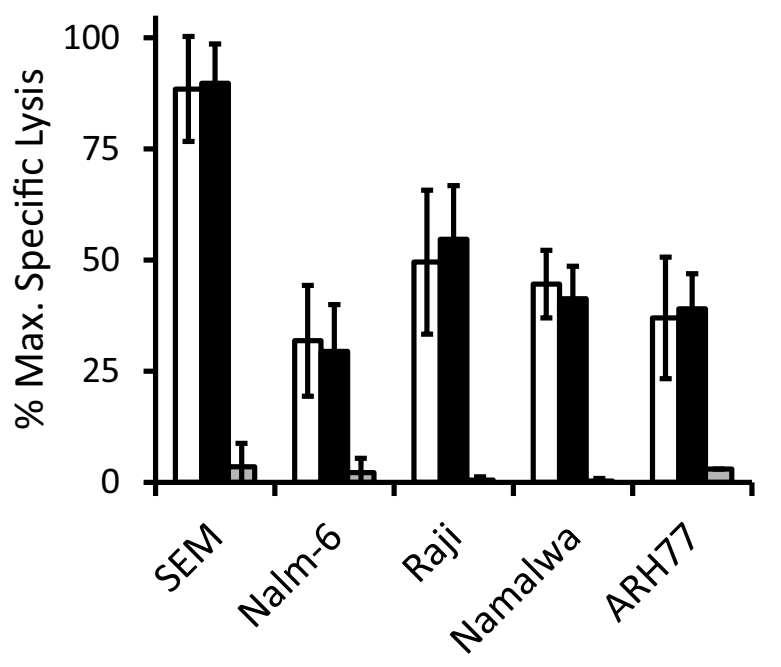

C

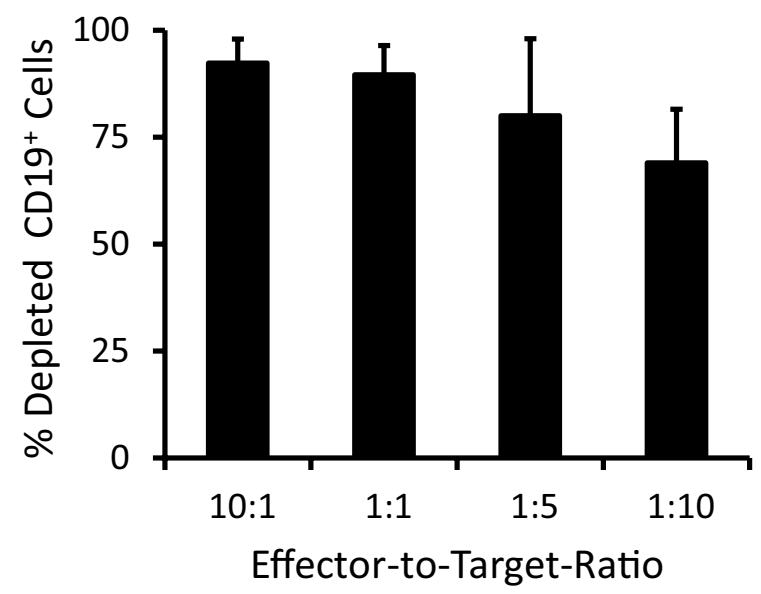

Figure 4: Specific redirected lysis of malignant target cell lines mediated by the 19-3 BiTE and triplebody 19-3-19 in conjunction with effector T cells. Standard Calcein Release Assays with an E : T ratio of 10:1 (MNCs : target cells) and a duration of 3 hrs were performed unless indicated otherwise. Error bars indicate SEM. (A) Dose-Response-Curve for SEM cells (triangles: triplebody 19-3-19; squares: 19-3 BiTE; cross: specificity control Her2-3-Her2; n=4). (B) Maximum specific lysis of several CD19-positive malignant B-lymphoid cell lines ( $\mathrm{n}=4$ each) induced by 19-3 (white bars), triplebody 19-3-19 (black bars) and specificity control Her2-3-Her2 (grey bars), respectively. (C) Serial lysis of unlabeled SEM target cells mediated by triplebody 19-3-19 at different E : T ratios. The reaction mixture (purified T cells and SEM target cells in RPMI1640 GlutaMAX medium containing 10\% FCS) was incubated with or without $1 \mathrm{nM}$ triplebody overnight (approx. $15 \mathrm{hrs})(\mathrm{n}=3)$. The total number of viable cells in each reaction was determined and the fraction of CD19positive target cells was established by FACS analysis. 
were also recorded for Nalm-6 (pre-B ALL), Raji (Burkitt lymphoma), Namalwa (Burkitt lymphoma) and ARH77 (plasma cell leukemia) cells and EC50-values were in the low picomolar range (Table 2). The specificity control triplebody Her2-3-Her2 did not induce significant lysis of any of the target cell lines (Fig. 4B). Different surface antigen densities of CD19 on these cell lines are an explanation for the difference in lysis measured, because a loose correlation was observed between the copy number of CD19 molecules per cell and the degree of maximum specific lysis (Fig. 4B and Table 2). Copy numbers per cell (given in the parentheses) were measured by calibrated cytofluorimetry and gave rise to the following ranking: $\operatorname{SEM}(30,000 \pm 8,000)>$ Raji $(23,500 \pm 19,000)>$ Nalm-6 $(17,500 \pm 7,000)>$ Namalwa $(7,000 \pm 4,000)>\operatorname{ARH} 77(1,500 \pm 2,000)$. Numbers of CD19 copies per cell were weakly correlated with the degree of maximum specific lysis achieved for these cell lines (Table 2) with the exception of Nalm-6 cells. Nalm- 6 cells carried intermediate numbers of CD19 copies per cell but responded poorly to lysis mediated by the triplebody plus T cells. Finally, no statistically significant difference between the degree of maximum lysis of these cell lines reached by $\mathrm{T}$ cells in combination with either the triplebody 19-3-19 or the BiTE 19-3 was observed ( $p$-values $>0.05$; Table 2 ). Thus, both agents mediated comparable maximum lysis of different types of malignant B-lymphoid cells.

\section{Triplebody 19-3-19 induces serial tumor cell lysis.}

Cytolytic $\mathrm{T}$ cells alone and $\mathrm{T}$ cells recruited by Blinatumomab ${ }^{\mathrm{TM}}$ are capable of serial target cell lysis.[19] This is a valuable property for therapeutic efficacy, and therefore we sought to determine, whether T cells recruited by 19-3-19 were also capable of serial lysis. Redirected lysis experiments were performed for an extended reaction period of $15 \mathrm{hrs}$ with a constant saturating concentration of 19-3-19 (1 nM), constant numbers of target cells, but decreasing effector-to-target cell ratios over the range from $10: 1$ to $1: 10$ (Fig. 4C). Even at an effector : target cell ratio of $1: 10,69 \pm 13 \%$ of the CD19-positive target cells were lysed, which provides clear evidence for serial lysis by $\mathrm{T}$ cells mediated by the triplebody.

\section{Activation of resting $\mathrm{T}$ cells via synapse-formation mediated by 19-3-19.}

Under physiological equilibrium conditions $\mathrm{T}$ cells in human blood are not activated unless an immune response is raised to a pathogen. Consequently, a therapeutic agent based on $\mathrm{T}$ cell-engagement may also require the activation of resting $\mathrm{T}$ cells to develop maximum efficacy. The BiTE Blinatumomab ${ }^{\mathrm{TM}}$ has already been shown to cause the activation of memory $\mathrm{T}$ cells, which (differing from naive $\mathrm{T}$ cells) do not require a second activation signal, and to trigger their proliferation. [20-22] To investigate whether triplebody 19-3-19 is capable of activating resting $\mathrm{T}$ cells when it connects the target and effector cell via the CD3E-specific scFv domain, a long-term (72 hr) RDL assay was performed using non-stimulated PBMCs from healthy unrelated donors as a source of effector cells and SEM cells as targets at an E : T ratio of $10: 1$ (PBMCs : targets).

The population of PBMCs from healthy donors includes both CD19- and CD3-positive cells and therefore, the frequencies of these subsets within the PBMC populations were measured for each donor prior to their use in RDL assays. For the panel of donors tested, the CD19positive subset ranged from 0.8 to $12.6 \%$ and the $\mathrm{T}$ cell subset from 69.3 to $74.5 \%$ of all PBMCs, respectively.

At the start of these experiments (time $t_{0}$ ) the CD19positive cellular subset accounted for 11.6 to $19.6 \%$ of all cells (PBMCs plus target SEM cells) in the reaction

\section{Table 2. Maximum lysis and EC50 values of 19-3 bispecific scFv and triplebody 19-3-19 for different malignant B-lymphoid cell lines.}

\begin{tabular}{|c|c|c|c|c|c|c|c|c|}
\hline \multirow{2}{*}{\multicolumn{2}{|c|}{ Cell Line }} & \multicolumn{3}{|c|}{ Maximum Specific Lysis [\%] } & \multicolumn{3}{|c|}{ EC50 [pM] (95\% CI [pM]) } & \multirow{2}{*}{$\mathbf{n}$} \\
\hline & & $19-3$ & 19-3-19 & p-value & $19-3$ & 19-3-19 & p-value & \\
\hline \multirow[t]{2}{*}{ pro-B ALL } & SEM & $88.5 \pm 12$ & $89.8 \pm 9$ & 0.33 & $4.5(2-10)$ & $5.5(3-9)$ & 0.43 & 4 \\
\hline & Nalm-6 & $31.9 \pm 12$ & $29.5 \pm 11$ & 0.08 & $12.7(5-30)$ & $22.3(16-31)$ & 0.21 & 4 \\
\hline \multirow[t]{2}{*}{$\begin{array}{l}\text { Burkitt } \\
\text { lymphoma }\end{array}$} & Raji & $49.6 \pm 16$ & $54.7 \pm 12$ & 0.1 & $1.8(0.5-7)$ & $47.4(11-201)$ & 0.053 & 4 \\
\hline & Namalwa & $44.6 \pm 8$ & $41.3 \pm 7$ & 0.12 & $6.2(32-12)$ & $19.9(9-43)$ & 0.071 & 4 \\
\hline $\begin{array}{l}\text { plasma cell } \\
\text { leukemia }\end{array}$ & ARH77 & $37.0 \pm 14$ & $39.0 \pm 8$ & 0.34 & $5.6(0.3-95)$ & $189.6(54-664)$ & 0.003 & 4 \\
\hline
\end{tabular}


mixture. The decreasing fraction of CD19-positive cells, the number of memory $\mathrm{T}$ cells $\left(\mathrm{CD}^{+} \mathrm{CD}^{+} 5 \mathrm{RO}^{+}\right)$, the expression levels of the early $\mathrm{T}$ cell activation marker CD69 (trans-membrane C-type lectin) and of the late activation marker CD25 ( $\alpha$-subunit of the IL-2 receptor) on CD3-positive cells were then assessed every 24 hrs (Fig. 5).

$\mathrm{T}$ cell activation was induced in all donor samples tested, but with extensive inter-donor variability (data not shown). The $\mathrm{T}$ cell activation profile from one particular 28-yr old male donor is shown in Fig. 5. After $24 \mathrm{hrs} 92.5 \%$ (values ranging from 86.0 to $99.4 \%$ lysis for different donors) of CD19-positive target cells were depleted (Fig. 5A). Maximum depletion of targeted cancer cells was generally achieved after 48 hrs (94.2 to $99.6 \%$ lysis). The control triplebody Her2-3-Her2 did not induce T cell activation as determined by activation marker expression (Fig. 5B) and Interferon- $\gamma$ release (data not shown).

A

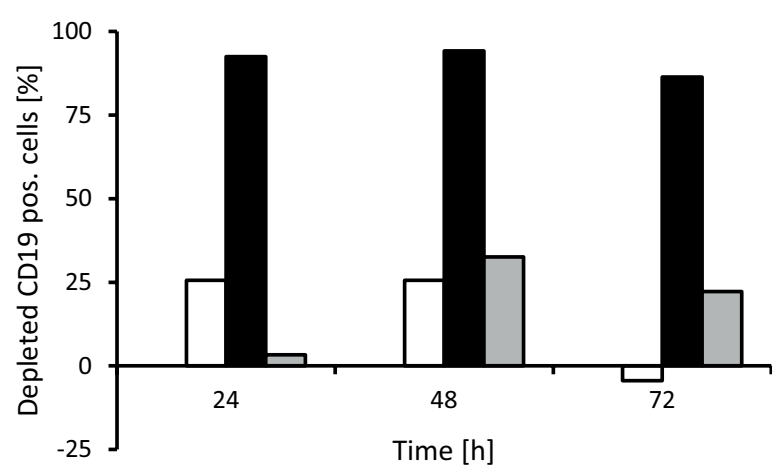

C

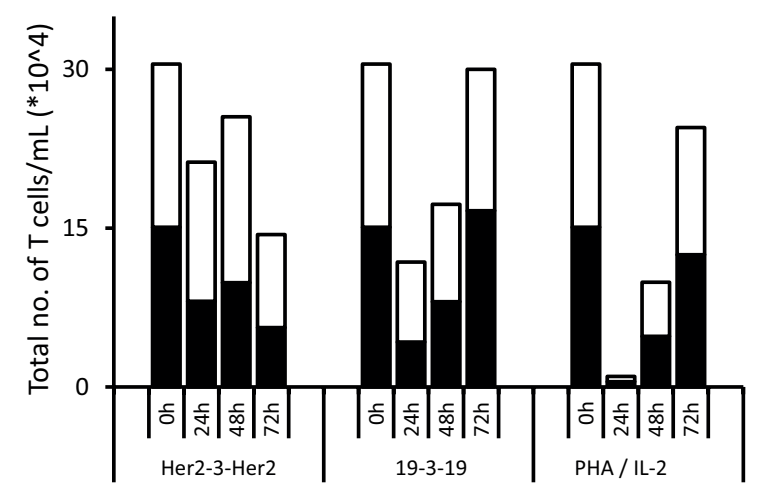

In all donor samples the addition of 19-3-19 or PHA/IL-2 (positive control) to the reaction mixture caused a strong increase of the early activation marker CD69 on the surface of the CD3-positive cells (Fig. 5B, red) within the first $24 \mathrm{hrs}$. At later time points the CD69 levels dropped progressively for the rest of the time course. Surface expression of CD25 was also induced, but less intensely and slower than CD69 and also varied greatly among the different donor samples. CD25 expression levels, induced by the triplebody, peaked between 24 to $48 \mathrm{hrs}$ and remained almost constant for the later time points (Figure 5B, black). In contrast, addition of the Her2-3-Her2 control triplebody caused no changes in CD69 or CD25 expression in the CD3-positive T cells. Addition of the triplebody 19-3-19 alone to the effector cells in the absence of CD19-positive target cells did not have any effect on the $\mathrm{T}$ cell population (data not shown).

B

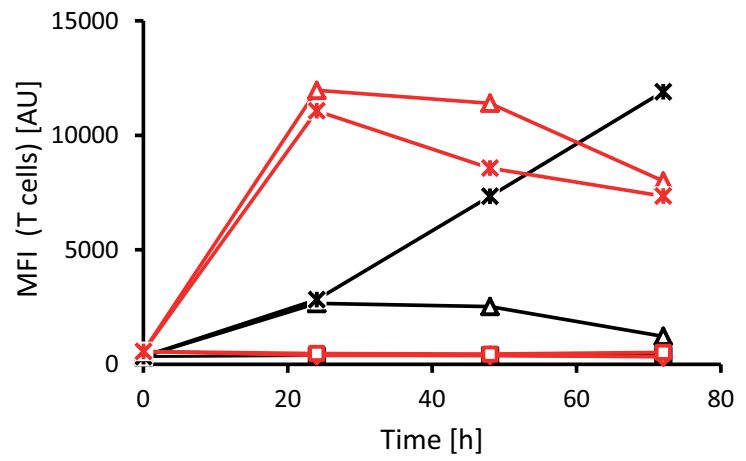

D

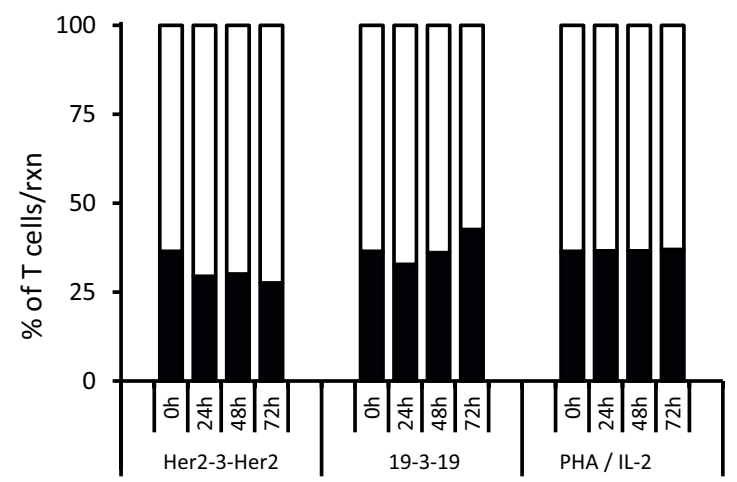

Figure 5: Example of $T$ cell activation induced by triplebody 19-3-19. Long-term (72 hrs) redirected lysis assay with an E : $T$ ratio of $10: 1$ non-stimulated PBMCs : SEM target cells and $1 \mathrm{nM}$ triplebody or $2 \%$ PHA/100 U/mL IL-2 (pos. control) were performed and the expression of activation markers by the effector $\mathrm{T}$ cells was assessed at 0, 24, 48 and $72 \mathrm{hrs}$ ( $\mathrm{n}=4$ ). Representative data from one 28-yr old, healthy male donor are shown. The CD3-positive cells comprised $70.4 \%$ of the donor's PBMC fraction and the CD19positive cells of the donor comprised $4.5 \%$ of his PBMCs. At time $t_{0}$ the overall content of CD19-positive cells in the reaction mixture (PBMCs + SEMs) was $14.6 \%$. (A) Depletion of CD19-positive target cells over time (white bars = triplebody Her2-3-Her2; black bars = triplebody 19-3-19; grey bars = $2 \%$ PHA/100 U/mL IL-2). (B) Time course of expression of early T cell activation marker CD69 (red) and late activation marker CD25 (black) on the cell surface. The increase in activation marker expression coincided with elevated IFN- $\gamma$ concentrations in the supernatant (data not shown). Diamonds: no treatment; squares: treatment with triplebody Her2-3-Her2; triangles: treated with triplebody 19-3-19; crosses: treated with $2 \% \mathrm{PHA} / 100 \mathrm{U} / \mathrm{mL}$ of IL-2. (C) Absolute number of T cells (CD3 ${ }^{+}$cells) and memory $\mathrm{T}$ cells $\left(\mathrm{CD}^{+} \mathrm{CD}^{2} 5 \mathrm{RO}^{+}\right.$, dark area) in the reaction mixture. (D) Fraction of memory $\mathrm{T}$ cells $\left(\mathrm{CD}^{+} \mathrm{CD}^{+} 5 \mathrm{RO}^{+}\right.$, dark area) in the total CD3-positive cellular compartment, which was set to $100 \%$. 
Therefore, the triplebody only caused activation of the effector T cells, when it physically connected the effector and the target cells in an antigen-specific manner and engaged them to build a productive synapse.

In the redirected lysis (RDL) experiments with triplebody 19-3-19 or PHA/IL-2 the overall numbers of living $\mathrm{T}$ cells dropped during the first one to two days, but rose again and reached the numbers present in the starting population after $72 \mathrm{hrs}$ (shown for the 28-yr old male donor sample in Fig. 5C). The subset of the CD3-positive population defined as memory $\mathrm{T}$ cells $\left(\mathrm{CD}^{+} \mathrm{CD}^{+} 4 \mathrm{RO}^{+}\right)$ also followed the drop and increase over time (Fig. 5D). We conclude that the $\mathrm{T}$ cell-recruiting triplebody can engage and activate memory $\mathrm{T}$ cells and induce their proliferation.

\section{Triplebody 19-3-19 mediates efficient lysis of CD19-positive malignant cells in primary patient samples.}

To determine the effect of an ex vivo treatment of patient cells with triplebody 19-3-19 plus effector cells, primary patient samples were used as malignant targets. PBMC fractions from five patients with different types of B cell malignancies were isolated by density gradient centrifugation and then employed as targets in our Calcein release RDL assays. The first patient suffered from an unusual case of tri-phenotypic acute leukemia (expressing B- and T-lymphoid plus myeloid lineage markers) and donated blood at diagnosis. Whole blood samples were also collected at diagnosis from an immunocytoma patient and two B-CLL patients. Finally, a blood sample from a B-CLL patient, who had relapsed 4 years after a complete remission and who had received 6 courses of combination therapy using MabThera ${ }^{\circledR}$ plus fludarabine and cyclophosphamide, was collected. This patient still displayed low expression of approximately 1,800 copies/cell of CD20 on its surface (Table 3, bottom). Patient characteristics are summarized in table 3.

Dose-responses for each patient sample were determined, using either our 19-3 BiTE, the triplebody 19-3-19, or the therapeutic CD20 antibody MabThera ${ }^{\circledR}$ and were assessed with standard $3 \mathrm{hr}$ Calcein releaseassays using allogeneic, ex vivo expanded MNC effector

Table 3. Synopsis of patient data. Patient characteristics (top), target and effector cell content (center) and specific antibody binding capacity for CD3, CD19, CD20 and CD33 of malignant cells in the peripheral blood as determined with the QIFIKIT (Dako) (bottom).

\begin{tabular}{|c|c|c|c|c|c|c|}
\hline & & $\begin{array}{l}\text { Patient } 1 \\
\text { (green) }\end{array}$ & Patient 2 (red) & $\begin{array}{l}\text { Patient } 3 \\
\text { (blue) }\end{array}$ & Patient 4 (yellow) & $\begin{array}{l}\text { Patient } 5 \\
\text { (purple) }\end{array}$ \\
\hline Gender & & Male & Male & Male & Female & Male \\
\hline Age & & 19 years & 86 years & 78 years & 67 years & 52 years \\
\hline Diagnosis & & $\begin{array}{l}\text { Mixed } \\
\text { phenotype } \\
\text { acute leukemia } \\
\text { (MPAL (NOS)) }\end{array}$ & $\begin{array}{l}\text { CD19-positive } \\
\text { NHL with } \\
\text { leukemic } \\
\text { progression }\end{array}$ & B-CLL & Relapsed B-CLL & B-CLL \\
\hline Blast titer & & $\begin{array}{l}93.4 \% \text { blasts in } \\
\mathrm{BM} \text { at diagnosis }\end{array}$ & $\begin{array}{l}58 \% \text { of } \\
\text { lymphocytes } \\
\text { in the PB are } \\
\text { CD19-positive }\end{array}$ & $\begin{array}{l}29,000 \text { B-CLL } \\
\text { cells } / \mu \mathrm{L}\end{array}$ & $\begin{array}{l}65 \% \text { lymphocytes } \\
\text { in the PB ( } 9 \% \\
\text { atypical) }\end{array}$ & $\begin{array}{l}42 \% \\
\text { lymphocytes in } \\
\text { the PB }\end{array}$ \\
\hline Case history & & $\begin{array}{l}\text { newly } \\
\text { diagnosed }\end{array}$ & $\begin{array}{l}\text { newly } \\
\text { diagnosed }\end{array}$ & $\begin{array}{l}\text { newly } \\
\text { diagnosed }\end{array}$ & $\begin{array}{l}4 \text { years prior: } 6 \mathrm{x} \\
\text { MabThera }^{\circledR} \text { plus } \\
\text { fludarabine and } \\
\text { cyclophosphamide } \\
\text { > CR }\end{array}$ & $\begin{array}{l}\text { newly } \\
\text { diagnosed }\end{array}$ \\
\hline $\begin{array}{l}\text { \% CD19+ in } \\
\text { PBMCs }\end{array}$ & & 94.8 & 21 & 89.8 & 68.8 & 73.2 \\
\hline $\begin{array}{l}\% \mathrm{CD} 3+\text { in } \\
\text { PBMCs }\end{array}$ & & 0.8 & 56.1 & 6.8 & 16.6 & 8.6 \\
\hline \multirow{4}{*}{$\begin{array}{l}\text { Specific antibody } \\
\text { binding capacity } \\
\text { (SABC) of } \\
\text { tumour cells in the } \\
\text { peripheral blood }\end{array}$} & $\mathrm{CD} 3$ & 211 & n.d. & n.d. & n.d. & n.d. \\
\hline & CD19 & $8,400 \pm 2,800$ & $14,600 \pm 7,700$ & $9,600 \pm 500$ & $6,500 \pm 1,700$ & $7,600 \pm 1,900$ \\
\hline & CD20 & 0 & $19,400 \pm 2,200$ & $4,000 \pm 100$ & $1,800 \pm 300$ & $3,900 \pm 1,200$ \\
\hline & CD33 & 317 & n.d. & n.d. & n.d. & n.d. \\
\hline
\end{tabular}


cells (expanded in the presence of IL-2) from an unrelated healthy donor. The $\mathrm{E}: \mathrm{T}$ ratio (MNCs : targets) was $10: 1$, which corresponded to an actual $\mathrm{T}$ cell : target ratio of $5: 1$ and an NK cell : target ratio of $2: 1$.

The maximum cytolytic response of the three CD20-positive B-CLL patient samples (patients 3, 4 and 5) to both CD19-targeting antibody-derivatives was more pronounced than the response to the standard-ofcare reagent MabThera ${ }^{\circledR}$ (Fig. 6A). The malignant cells of these three patients had higher surface densities of
CD19 than of CD20 (Table 3, bottom), which paralleled the higher maximum specific lysis mediated by 19-3 and 19-3-19 than by MabThera ${ }^{\circledR}$. The sample from the immunocytoma patient (patient 2) responded more strongly to treatment with MabThera ${ }^{\circledR}$ than to treatment with either 19-3-19 or 19-3 (Fig. 6A). This coincides with a greater surface density of CD20 than CD19 on the malignant target cells from this patient (Table 3, bottom). The mixed phenotype acute leukemia (not otherwise specified) (MPAL(NOS)) patient sample (patient 1)
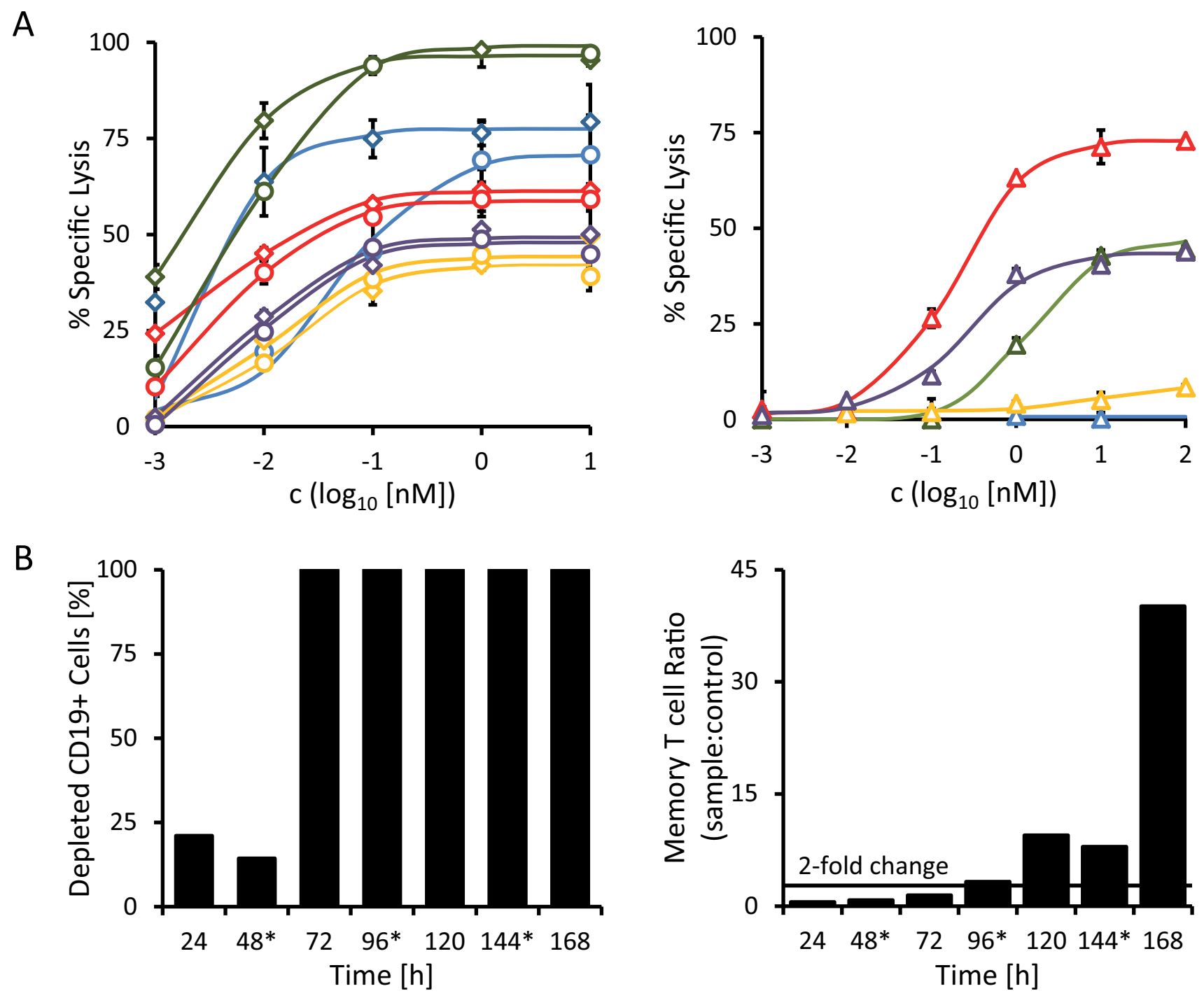

Figure 6: Redirected lysis of CD19-positive malignant cells from primary patient material mediated by triplebody 19-3-19. The ability of triplebody 19-3-19 to mediate the lysis of malignant cells isolated from the peripheral blood of patients with different B cell malignancies (see table 3) via allogeneic and autologous effector T cells was assessed in redirected lysis assays. Samples were assayed in triplicate. Error bars indicate intra-sample variation. (A) Specific lysis of malignant cells via allogeneic pre-stimulated effector T cells mediated at different concentrations of the 19-3 BiTE (diamonds) and triplebody 19-3-19 (circles) or the therapeutic antibody MabThera $^{\circledR}$ (triangles) in a $3 \mathrm{hr}$ assay, respectively. Patient 1 (MPAL (NOS)): blue; patient 2 (NHL): red; patient 3 (B-CLL): green; patient 4 (relapsed B-CLL): yellow; and patient 5 (B-CLL): purple. (B) Triplebody 19-3-19-induced depletion of CD19-positive cells by autologous effector T cells and expansion of memory T cells $\left(\mathrm{CD}^{+} \mathrm{CD}^{4} 5 \mathrm{RO}^{+}\right)$in the PBMC fraction isolated from patient 2 (NHL) in a $7 \mathrm{~d}$ assay. $1 \mathrm{nM}$ of fresh Triplebody 19-3-19 was added every $48 \mathrm{hrs}$ (indicated by asterisks). A similar assay was performed with samples from patients 1 (MPAL (NOS)) and 3 (B-CLL) (data not shown), but no response was observed, possibly due to the relatively short observation time, $\mathrm{T}$ cell attenuation or too low initial numbers of effector $\mathrm{T}$ cells. 
was CD20-negative and consequently failed to display any response to treatment with MabThera ${ }^{\circledR}$, but it did respond to treatment with both the 19-3 and 19-3-19 reagents (Fig. 6A). The response profile of this MPAL patient is more typical for patients with acute B-lymphoblastic leukemia often found in children and young adults, where the malignant blasts have a phenotype resembling early stages of B cell differentiation. Blasts from B cell precursor leukemias (BCP-ALLs) of infants, children and young adults often fail to express CD20, and thus these patients are more likely to benefit from treatment with a CD19-directed rather than a CD20-specific agent.[41, 42]

Triplebody 19-3-19 and our 19-3 BiTE reagent were effective at far lower concentrations than MabThera ${ }^{\circledR}$. Although inter-patient variation was substantial, the EC50values for 19-3 and 19-3-19 generally were 30- to 925-fold lower than those determined for MabThera ${ }^{\circledR}$ for the panel of patient samples analyzed here (Table 4). No statistically significant differences between the BiTE reagent and the triplebody were observed with regard to the degree of maximum lysis and the EC50 values. Interestingly, maximum lysis achieved with the triplebody was marginally lower than the extent reached with 19-3. Maximum specific lysis and EC50 values are summarized in Table 4.

\section{Triplebody 19-3-19 induces expansion of memory $T$ cells in a sample from an NHL patient.}

In patients with malignant hematopoietic diseases healthy immune effector cells are often displaced and suppressed. However, sufficient numbers of functioning effector cells are needed for a successful therapy with an agent critically relying on the recruitment of cytolytic effectors. By inducing the proliferation of memory $\mathrm{T}$ cells, the BiTE ${ }^{\circledR}$ agents Blinatumomab ${ }^{\mathrm{TM}}$ and AMG330 have caused an amplification of available effector cells.[20-22, 26] As the triplebody 19-3-19 also employs an OKT3-derived scFvdomain to trigger its effector cells, we investigated whether exposure to this triplebody was also capable of stimulating the proliferation of memory $\mathrm{T}$ cells in a patient sample. To this effect, the triplebody was added in a $1 \mathrm{nM}$ saturating concentration to PBMCs isolated from an immunocytoma patient (patient 2) every 48 hrs for 7 days. At timepoint $t_{0}$, the sample contained $21 \%$ CD19-positive cells and $56.1 \%$ CD3-positive cells (Table 3). Approximately half of the CD3- positive cells $(53.3 \%)$ expressed the memory $\mathrm{T}$ cell marker CD45RO on their surface. In this particular patient sample, the $\mathrm{T}$ cell population displayed the same initial drop in numbers during the first $24 \mathrm{hrs}$ that was also observed during the activation of $\mathrm{T}$ cells in the healthy donor samples reported above (Fig. 5). However, after 48 hrs, the T cells started to expand and the numbers of memory $\mathrm{T}$ cells had more than doubled after $96 \mathrm{hrs}$ in comparison to the control reaction without added triplebody. On day 7 , the numbers of memory $\mathrm{T}$ cells were increased by more than 42 -fold in the triplebodytreated sample (Fig. 6B, right). The overall $\mathrm{T}$ cell population expanded 7-fold during the $7 \mathrm{~d}$ period of observation despite the absence of detectable numbers of CD19-positive target cells from $72 \mathrm{hrs}$ on (Fig. 6B, left).

\section{DISCUSSION}

In the present study, the prototype $\mathrm{T}$ cell-recruiting triplebody 19-3-19 was constructed and shown to engage preactivated as well as non-stimulated T cells efficiently for the redirected and serial lysis of malignant CD19-positive target cells. Moreover, 19-3-19 led to the activation and induced the proliferation of allogeneic and autologous effector $\mathrm{T}$ cells. The key new result of the present study is the observation that fusion proteins in the molecular format of single chain triplebodies are also suited for the engagement of cytolytic T cells (CTLs) via CD3 $\varepsilon$ to eliminate antigen-positive cancer cell targets.

The concept of an "individualized therapy" usually refers to the selection of a specific therapeutic target based on a patient's individual genotypic and phenotypic characteristics, as determined by molecular diagnostics. However, another important aspect of personalized medicine, especially when planning to exploit or boost the patient's own immune system, is the size and activity of a suitable population of immune effector cells available at the cancer site. As a patient's immune status varies with the type and stage of the disease, different effector cell populations may be best suited in different situations. NK cells, for example, recover more rapidly than $\mathrm{T}$ and $\mathrm{B}$ lymphocytes after chemotherapy, and they require little activation time. They are present in the human circulation in a pre-activated state and are instantaneously ready for antibody-mediated cytolysis. Thus NK cells may be a suitable choice of effector cells to combat minimal residual disease after an induction

Table 4. Synopsis of maximum lysis and EC50 values for patient samples.

\begin{tabular}{|l|l|l|l|l|l|l|}
\hline \multicolumn{1}{c}{} & \multicolumn{3}{c}{ Maximum Specific Lysis [\%] } & \multicolumn{3}{c}{ EC50 [pM] (95\% CI [pM]) } \\
\cline { 2 - 8 } \multicolumn{1}{c|}{} & $\mathbf{1 9 - 3}$ & $\mathbf{1 9 - 3 - 1 9}$ & \multicolumn{1}{c}{ MabThera $^{\circledR}$} & $\mathbf{1 9 - 3}$ & \multicolumn{1}{c}{$\mathbf{1 9 - 3 - 1 9}$} & \multicolumn{1}{c|}{ MabThera $^{\circledR}$} \\
\hline Patient 1 & 79.3 & 70.8 & n.d. & $1.2(0.3-5)$ & $48.1(9-270)$ & n.d. \\
\hline Patient 2 & 61.5 & 59.2 & 72.8 & $6.1(4-10)$ & $4.8(3-9)$ & $185.7(135-255)$ \\
\hline Patient 3 & 98 & 100 & 44.5 & $2.8(1-8)$ & $6.4(4-11)$ & $1,300(426-4,224)$ \\
\hline Patient 4 & 49.4 & 44.7 & 8.4 & $10.7(1-177)$ & $13.9(2-84)$ & $9,900(0.1-568 \mathrm{nM})$ \\
\hline Patient 5 & 51.3 & 48.8 & 43.9 & $6.7(1-36)$ & $7.1(2-29)$ & $247.5(89-688)$ \\
\hline
\end{tabular}


chemotherapy.[3] $\mathrm{CD}^{+} \mathrm{T}$ cells, however, are frequently present in cancer tissues in abundance, have a greater intrinsic cytotoxic potential than NK cells, and are capable of more prolonged serial lysis.[43, 44] CTLs are therefore a particularly desirable class of cytolytic effectors for cancer therapy.

Ideally, for a fully individualized approach and to avoid successful immune evasion by the tumor cells, both the therapeutic target and the effector population should be chosen corresponding to the patient's individual disease properties. The molecular format of triplebodies may help to reach this goal, because triplebodies were found suited in this study to recruit not only NK cells but also T cells as cytolytic effectors.

Both the protein 19-3 in the BiTE-format and the newly constructed triplebody 19-3-19 were produced with similar expression yields and had similar cytolytic potential. Triplebody 19-3-19 led to efficient in vitro lysis of CD19-positive targets from both established malignant B-lymphoid cell lines and primary patient material at picomolar concentrations. Cell surface density of target antigens was a major, but not the only important determinant of cytolytic efficacy of the agent. A CD19positive cell line with high antigen surface expression (SEM) showed a greater degree of maximum lysis in a standard $3 \mathrm{hr}$ reaction interval in our redirected lysis experiments than cell lines with lower surface expression of the target antigen (Raji, Namalwa and ARH77).

The difference between maximum lysis of SEM cells $(89.8 \%)$ and Raji cells (54.7 \%) was significant, even though CD19 copy numbers per cell differed by only 6,500 copies between these two cell lines. However, the determination of antigen copy numbers per cell by calibrated cytofluorimetry does not take the actual cell size into account and therefore produces copy numbers per cell, but not antigen density values. We have observed that Raji cells (Burkitt's lymphoma-derived) are much larger than SEM cells (pro-B ALL-derived), and therefore, the antigen density per surface unit may be lower for Raji cells than for SEMs. However, this argumentation does not fully explain the low specific lysis achieved for Nalm6 cells. Nalm- 6 cells have a relatively small cell volume that is comparable to SEMs and carried 17,500 copies of CD19/cell, but resulted in only 31.9 and $29.5 \%$ specific lysis mediated by 19-3 and 19-3-19, respectively, which were the lowest values observed. Additional parameters other than antigen surface density appear to play important roles in determining the sensitivity of a target cell to T cellmediated lysis, probably linked to the specific oncogenic genomic and epigenetic alterations of the particular target and their tumor-type specific susceptibilities to apoptosis.

The triplebody 19-3-19 induced a similar $\mathrm{T}$ cell response profile as Blinatumomab ${ }^{\mathrm{TM}}$. Activation of the $\mathrm{T}$ cell by this triplebody only occurred when the $\mathrm{T}$ cells were connected to the target cells by the triplebody in an antigen-specific manner, but was independent of specific
MHC : peptide recognition. Furthermore, memory T cells rather than naïve $T$ cells were engaged and induced to proliferate. Whether the triplebody also affects the activation state of naïve $T$ cells, i.e. whether naïve $T$ cells remain resting or are forced into anergy due to the interaction of 19-3-19 with CD3 in the absence of any "second signal" (co-stimulus), remains to be determined.

Interestingly, the CD3e-specific $\mathrm{scFv}$ of 19-319 bound less efficiently to primary $\mathrm{T}$ cells than when this domain was embedded in our 19-3 BiTE protein or the Her2-3-Her2 control protein, when each was used at saturating concentrations. Together with the lower affinity of 19-3-19 for CD3 $\varepsilon$ in comparison to 19-3, these observations indicate that $\mathrm{CD} 3 \varepsilon$ on the surface of the $\mathrm{T}$ cells is less available for binding by the triplebody 19-3-19 than by triplebody Her2-3-Her2 and by the 19-3 protein. We cannot yet offer a definitive explanation for this observation, but the precise conformation of the $\mathrm{CD} 3 \varepsilon$-specific $\mathrm{scFv}$ is likely different, when it is flanked at both sides by CD19specific scFvs or Her2-specific scFvs, or only at one side by a single CD19-specific scFv. One possibility may be partial sterical hindrance of the $\mathrm{CD} 3 \varepsilon$-specific $\mathrm{scFv}$ by the two distal CD19 scFvs, which may impact affinity.

A sensitivity of $\mathrm{CD} 3 \varepsilon$-specific scFvs to their precise molecular surroundings has been previously reported by other authors. In the hands of M. Arndt and colleagues the $\mathrm{CD} 3 \varepsilon$-specific $\mathrm{scFv}$ required optimization for every different BiTE construct, which led to the development of a new modular targeting system by these authors.[13] Further development of previously reported trispecific $\mathrm{T}$ cell-engaging antibody-derivatives, which employed an N-terminal tumor-associated antigen (TAA)-specific $\mathrm{scFv}$, a central CD3E-specific scFv or $\mathrm{V}_{\mathrm{H}}$ domain, and a C-terminal CD28-specific $\mathrm{V}_{\mathrm{H}}$ domain in one polypeptide chain, $[45,46]$ was discontinued. The question, whether the $\mathrm{CD} 3 \varepsilon$-specific $\mathrm{scFv}$ domain in the central position of these fusion proteins was stable and functional, remained unanswered.

The value of triplebodies recruiting effector $\mathrm{T}$ cells can most likely be further increased by taking advantage of the unique capability of triplebodies for "dualtargeting". Dual-targeting has been reported to enhance the selectivity of triplebodies recruiting NK cells as cytolytic effectors,[38] but it needs to be determined whether a preferential lysis of antigen double-positive cells over simultaneously present antigen single-positive cells can also be achieved by dual-targeting triplebodies, which recruit $\mathrm{T}$ cells as effectors. This may not be a foregone conclusion, because results recently reported by Harms and colleagues about the cross-arm binding efficiencies of monoclonal antibodies and different multispecific antibody-derived formats[47] suggest, that not every target combination leads to an improved antibody-activity in spite of the higher combined target antigen density. This may be explained in part by the "protein island"model of the cell membrane, which is currently one of the 
most potent models for the surface architecture of human leukocytes.[48, 49] This model proposes that the surface of human leukocytes is composed of "protein islands" of approximately 200-300 $\mathrm{nm}$ in diameter. Particular groups of proteins are segregated in separate islands. They are anchored to the cytoskeleton by protein contacts, and the lipid composition within the islands is different from the areas outside of the islands. The islands have a degree of freedom for lateral movement on the surface, and specific events can cause the relocation of one island into the immediate vicinity of another to facilitate protein interaction. This has been reported for example for the $\mathrm{T}$ cell antigen receptor (TCR) and its co-factor Lat.[49] On the surface of resting $\mathrm{T}$ cells these two proteins were found in different protein islands, which concatenated upon $\mathrm{T}$ cell activation. If we assume this model to be valid, and if two antigens, which are targeted by a multispecific antibody-derivative such as our triplebody, reside in separate protein islands, and if the intrinsic cross-arm binding property of the employed molecule is unsuited for simultaneous binding, and if none of the two antigens can relocate to the other island, then there is no benefit in multispecificity. However, if two different antigens can be bound simultaneously on the same cell, then cancer cell selectivity may be possible and several immunotherapeutic mechanisms of action, such as growth factor receptor inhibition, neutralization of immune evasion mechanisms, or induction of apoptosis and ADCC (or RDL), can potentially be combined.

In this proof-of-principle study, we have demonstrated that triplebodies which are bivalent, but monospecific for the target antigen, can recruit one of the most desirable effector cell populations, the cytolytic $\mathrm{T}$ cells, for cancer cell lysis. It remains to be investigated in future studies, whether it is possible to further enhance the value of $\mathrm{T}$ cell-recruiting triplebodies as potential therapeutic agents by endowing them with the dualtargeting option, based on the rational choice of a pair of target antigens on the cancer cell, which is more abundant and/or more accessible on the surface of the cancer cell than on the corresponding healthy cells. It also remains to be seen, whether the triplebodies have the improved plasma half-life relative to the BiTE agents in humans, which has been demonstrated for them in mice. However, we anticipate that both of these goals are within reach, and therefore, that triplebodies have significant therapeutic potential for the treatment of cancer and other diseases.

\section{METHODS}

\section{Bacterial strains and cell lines}

DNA plasmids for the eukaryotic expression of antibody-derived fusion proteins were amplified in Escherichia coli strain XL-1. The mammalian production cell line $293 \mathrm{~F}$ was purchased from Life Technologies ${ }^{\mathrm{TM}}$ and cultured in serum-free FreeStyle ${ }^{\mathrm{TM}}$ medium (Life Technologies $^{\mathrm{TM}}$ ). The pro B-ALL cell line SEM has been continuously propagated in our laboratory since its establishment in 1995,[50] the CD19-positive pre-B cell line Nalm-6, the Burkitt lymphoma cell lines Raji and Namalwa and the plasma cell leukemia cell line ARH77 were purchased from the Leibniz Institute DSMZ (German Collection of Microorganisms and Cell Cultures).[51] All cell lines were cultured in RPMI 1640, GlutaMAX ${ }^{\mathrm{TM}}$ supplemented with $10 \%$ fetal calf serum (FCS) and Penicillin $(100 \mathrm{U} / \mathrm{mL}) /$ Streptomycin $(100 \mu \mathrm{g} / \mathrm{mL})$ $\left(\right.$ Gibco $^{\circledR}$, Life Technologies $\left.{ }^{\mathrm{TM}}\right)$. The medium for the Namalwa cell line was additionally supplemented with $1 \mathrm{mM}$ sodium pyruvate.

\section{Construction, expression and purification of triplebody 19-3-19 and control proteins}

All antibody derivatives employed in this study were cloned into the mammalian expression vector pSecTag2-HygroC (Life Technologies ${ }^{\mathrm{TM}}$ ). The $\mathrm{scFv}$ building blocks for the bispecific $\mathrm{scFv}$ proteins 19-3 and the Her2-3, and for the triplebodies 19-3-19 and Her23-Her2 were developed by our team at the University of Erlangen (CD19-specific scFv) or provided by M. Peipp (University of Schleswig-Holstein, Kiel; CD3 $\varepsilon$ - and Her2specific scFvs), respectively. The sequences coding for the disulfide-stabilized CD16-specific scFv in the gene encoding the triplebody 19-16-19 (derived from Kellner et al. 2008, but with humanized $\mathrm{scFv}$ sequences) were replaced with the murine $\mathrm{CD} 3 \varepsilon$-specific $\mathrm{scFv}$ sequence amplified by polymerase chain reaction (PCR) from the sequence coding for Her2-3 by standard molecular cloning methods. Similarly, the sequences coding for the Her2-specific $\mathrm{scFv}$ in the Her2-3 construct were replaced with the sequences coding for the humanized CD19-specific scFv to produce the coding sequences for 19-3. The sequences coding for the CD19-specific scFvs in the coding construct for triplebody 19-3-19 were replaced with coding sequences for the Her2-specific $\mathrm{scFv}$ amplified by PCR from the construct coding for Her2-3 to produce the coding sequences for triplebody Her2-3-Her2. (Details of the construction scheme are listed in Supplementary Table S1). 293F cells were transfected with the respective expression vectors using the TransIT ${ }^{\circledR}$-LT1 transfection reagent (Mirus ${ }^{\circledR}$ Bio LLC) following manufacturer's instructions. Antibody-derived fusion proteins were purified by affinity chromatography from cell culture supernatants that were harvested 7 days post transfection. A Nickel-nitrilo triacetic acid (Ni-NTA) matrix was used. Protein concentrations were determined by measurement of their absorbance at $280 \mathrm{~nm}$. Protein identity was confirmed and purity assessed by SDSpolyacrylamide gel electrophoresis and Western Blotting 
(N-terminal integrity confirmed with anti-Strep- and $\mathrm{C}$-terminal integrity confirmed with anti-His antibodies).

\section{Preparation of peripheral blood mononuclear cells (PBMCs) from whole blood}

$10-60 \mathrm{~mL}$ of peripheral blood was drawn into EDTA monovettes (Sarstedt) from healthy unrelated donors and patients suffering from different types of B cell neoplasias, after informed written consent was obtained. This study is in accordance with the declaration of Helsinki and was approved by the ethics committee of the Medical Faculty of the Ludwig-Maximilians-Universität München (project no. 173-13). PBMCs were separated by density gradient centrifugation using Lymphoprep ${ }^{\mathrm{TM}}$ (Axis Shield PoC) medium, and residual erythrocytes were lysed by incubation with Ery-Lysis-Buffer (University Pharmacy, Munich) for 5 min. To generate effector cells for standard $3 \mathrm{hr}$ cytotoxicity assays, an ex vivo expansion and stimulation of mononuclear cells (MNCs) was carried out for $20 \mathrm{~d}$ in the presence of IL-2 as described.[52] For $\mathrm{T}$ cell activation assays freshly isolated, non-stimulated PBMCs were used.

\section{Enrichment of a pan $T$ cell population by preparative magnetic cell separation}

Pan $\mathrm{T}$ cells were isolated from ex vivo expanded MNCs or freshly isolated, non-stimulated PBMCs by negative selection using a commercial Pan T cell isolation kit (Miltenyi Biotec, Bergisch Gladbach, Germany) according to the manufacturer's instructions. The enriched $\mathrm{T}$ cells are referred to as "untouched cells" because they have no residual antibody bound to their surface and have been maintained under mild buffer/medium conditions. $T$ cell purity was assessed by flow cytometry and the purified $\mathrm{T}$ cells were used for binding and $\mathrm{T}$ cell activation studies.

\section{Flow cytometry}

An Accuri C6 flow cytometer (BD Biosciences, Heidelberg, Germany) was used for flow cytometric analysis of the binding behavior of the antibody-derived fusion proteins and for the differential analysis of leukocyte/tumor cell subpopulations. In the Accuri C6 instrument the laser and optical alignments have been preset and locked. In this instrument the detector voltages are not adjustable as opposed to other machines. Equilibrium binding constants (affinity constants, $\mathrm{K}_{\mathrm{D}}$ ) for CD19 and CD3 were determined by calibrated cytofluorimetry. [53] The maximum mean fluorescence value was set to $100 \%$ and all data points were normalized accordingly. Experiments were repeated 4 to 7 times and $K_{D}$ values were calculated with the GraphPad Prism Software (GraphPad Software Inc., San Diego, CA, USA) using a nonlinear regression curve fit. Cell-bound antibody-derivatives were detected using a Penta-His ${ }^{\mathrm{TM}}$ AlexaFluor488-conjugated antibody (QIAGEN, Hilden, Germany). The CD3-, CD4-, CD8-, CD19-, CD25-, CD33-, CD45RA-, CD45RO-, CD56- and CD69-specific monoclonal antibodies (mAbs) used for the analysis of lymphocyte and myeloid cell content and for the detailed analysis of relevant $\mathrm{T}$ cell subpopulations as well as the respective isotype control $\mathrm{mAbs}$ were from Immunotech (Marseille, France). Specific antibody binding capacity of cells from established B-ALL lines and primary leukemia blasts for $\mathrm{CD} 3$ (unconjugated $\mathrm{mAb}$ from ebioscience, Frankfurt, Germany), CD19 (unconjugated mAb from DAKO, Hamburg, Germany), and CD33 (unconjugated mAbs from BD Pharmingen, Heidelberg, Germany) was determined with a commercial calibrated cytofluorimetric assay (QIFIKIT ${ }^{\circledR}$, DAKO, Hamburg, Germany) as described.[54, 55]

\section{Cytotoxicity assay}

To quantitate cell-mediated cytolysis (referred to as redirected lysis, RDL) induced by the BiTE or triplebody proteins, target cells were pre-labelled with Calcein AM (Life Technologies) and mixed with effector cells in RPMI 1640 GlutaMAX medium supplemented with $10 \%$ fetal calf serum at an $\mathrm{E}: \mathrm{T}$ ratio of $10: 1$ unless otherwise stated. Either MNCs expanded ex vivo for 20 days and pre-stimulated with anti-CD3 mAb OKT3 and IL-2,[11, 56] or untouched $T$ cells isolated via magnetic separation, were used as effector cells. After addition of different antibody-derived proteins to $200 \mu \mathrm{L}$ reaction volume in round-bottom 96 -well plates, the reactions were incubated at $37{ }^{\circ} \mathrm{C}$ with $5 \% \mathrm{CO}_{2}$. Calcein release was determined by measuring the fluorescence intensity (relative light units, RLU) in the supernatant with a Berthold Mithras plate reader (Berthold technologies, Bad Wildbad, Germany). Maximum lysis was achieved by addition of $50 \mu \mathrm{L}$ of a solution containing $10 \%$ Triton X-100 in RPMI 1640 GlutaMAX medium supplemented with $10 \%$ fetal calf serum and $1 \%$ Penicillin/Streptomycin. Specific lysis was calculated as follows:

$$
\begin{gathered}
\text { \% specific Lysis }=100 *[\text { RLU (sample) } \\
- \text { RLU (background)] / [RLU (maximal lysis) } \\
- \text { RLU (background) }]
\end{gathered}
$$

\section{$T$ cell activation assay}

Activation of resting $\mathrm{T}$ cells was determined by measurement of IFN- $\gamma$ release and the expression of the early activation surface marker CD69 and the late activation marker CD25, the alpha-subunit of the highaffinity receptor for interleukin-2 (IL-2R). Freshly isolated PBMCs from healthy unrelated donors remained either untouched, were depleted of CD19-positive cells by magnetic separation, or were mixed with SEM cells at an $\mathrm{E}: \mathrm{T}$ ratio of $10: 1$. Triplebody was added at a 
concentration of $1 \mathrm{nM}$ to a $280 \mu \mathrm{L}$ reaction mixture containing $1,4 * 10^{\wedge} 5$ PBMCs with or without $1.4^{*} 10^{\wedge} 4$ SEMs in RPMI $1640+$ GlutaMAX ${ }^{\mathrm{TM}}$ medium with $10 \%$ FCS and $1 \%$ Pen/Strep (Gibco ${ }^{\circledR}$, Life Technologies ${ }^{\mathrm{TM}}$ ). After incubation for $0,24,48$ and $72 \mathrm{hrs}$ the total number of living cells in the reaction mixture was determined with a hemocytometer (Marienfeld Superior, Lauda-Königshofen, Germany) using Trypan Blue staining $\left(\right.$ Gibco $^{\circledR}$, Life Technologies $\left.{ }^{\mathrm{TM}}\right)$. The surviving cells were stained for CD3/CD19, CD3/CD25, CD3/ CD69 and CD3/CD45RO and the fraction of the relevant cell populations (CD19-positive targets, CD3-positive effectors, activated CD3-positive effectors and CD3 CD45RO double-positive memory T cells) was assessed by flow cytometry. The fraction of depleted B cells, i.e. the differential removed by the depletion, was computed with the help of the following formula:

$\%$ depleted B cells $=100 \% *\left(\mathrm{CD} 19^{+}\right.$cells control $\mathrm{CD} 19^{+}$cells sample $) /\left(\mathrm{CD} 19^{+}\right.$cells control $)$

\section{Measurement of IFN- $\gamma$ release into peripheral blood samples}

Induction of cytokine release by immune effector cells due to the presence of the triplebody or BiTE control molecule was determined in whole blood assays. Triplebodies 19-3-19 or Her2-3-Her2 or the protein 19-3 were added to $200 \mu \mathrm{L}$ of peripheral blood in a roundbottom Nunc ${ }^{\text {TM }}$ 96-Microwell plate (ThermoFisher Scientific, MA, USA) at different concentrations and were incubated for $6 \mathrm{hrs}$ at $37{ }^{\circ} \mathrm{C}$ with $5 \% \mathrm{CO}_{2}$. The samples were then diluted $1: 1$ with PBS and concentrations of IFN- $\gamma$ were determined using commercial Ready-Set-Go ELISA kits (ebioscience, Frankfurt, Germany). Depending on sample availability, samples were run in duplicates or triplicates.

\section{Statistical analysis}

All statistical analyses were performed by GraphPad Prism Software (GraphPad Software Inc., San Diego, CA, USA) using Student's t-test for the determination of significance, defined by $\mathrm{p}<0.05$.

\section{ABBREVIATIONS}

ADCC: antibody-dependent cellular cytotoxicity, ALL: acute lymphoblastic leukemia, B-CLL: chronic B cell leukemia, BiTE: bispecific T cell engager, bsscFv: bispecific single chain Fv, CD: cluster of differentiation, CI: confidence interval, CR: complete remission, EC50: concentration at which half maximal effect is achieved, ELISA: enzyme-linked immunosorbent assay, FACS: fluorescence-assisted cell sorting, IFN- $\square$ : Interferon gamma, IL-2: Interleukin-2, MFI: Mean Fluorescence Intensity, MNC: mononuclear cells, MPAL (NOS): mixed phenotype acute leukemia (not otherwise specified); NHL: Non-Hodgkin Lymphoma, PB: peripheral blood, PBMC: peripheral blood mononuclear cells, PCR: polymerase chain reaction, $\mathrm{PHA}$ : Phytohemagglutinin, $\mathrm{pI}$ : isoelectric point, pre-B cells: $\square$-positive, CD10 (CALLA)-positive; pro-B cells: $\square$-negative, CD10 (CALLA)-negative, RDL: redirected lysis assay, $\mathrm{scFv}$ : single chain fragment variable, SEM: standard error of the mean, TAA: tumorassociated antigen, TNF $\square$ : tumor necrosis factor alpha.

\section{Competing Interests}

The authors declare that they have no competing interests.

\section{AUTHORS' CONTRIBUTIONS}

CCR carried out the experiments and statistical analyses, participated in the project design and coordination and drafted the manuscript. CBS performed the DNA sequence optimization, helped in the establishment of a protein production and purification strategy and revised the manuscript. TAB, SK and IAS participated in the design of the project and revised the manuscript. GHF conceived of the study, participated in its design and helped to draft the manuscript. KPH and FSO participated in project design and coordination. All authors read and approved the final manuscript.

\section{ACKNOWLEDGEMENTS}

We thank Dr. Matthias Peipp for providing the pSecTag2-HygroC vector with the Her2-CD3 BiTE construct and Kerstin Lämmermann, Brigitte Schnabel, Alexandra Schele and Stefanie Nowecki for technical assistance. Guidance and scientific advice from Profs. Stefan Endres and Uwe Jacob, and Drs. Sarah Wildenhain and Nadja Fenn are gratefully acknowledged as well as fruitful scientific discussions with Nadine Moritz and Monika Herrmann. We also thank the healthy donors and patients, who provided blood samples for this study.

This study was supported by awards from the charity "Chimney Sweeps Help Children with Cancer" (Schornsteinfeger Helfen Krebskranken Kindern e.V.) to GHF, by support from the M4 excellence award to $\mathrm{KPH}, \mathrm{GHF}$ and FO from the Bavarian Government, by funding from the Munich Center for Integrated Protein Science (CiPSM) to KPH and by a Ph.D. student research fellowship awarded to CCR by the German José Carreras-Leukemia Foundation (www.carreras-stiftung .de, Scholarship No. DJCLS F 13/05). SK is supported by the Graduiertenkolleg 1202 "Oligonucleotides in cell biology and therapy" funded by the Deutsche Forschungsgemeinschaft, the international doctoral program "immunotargeting of cancer" funded by the Elite 
Network of Bavaria, the Melanoma Research Alliance (grant number N269626) and the Deutsche Krebshilfe.

\section{REFERENCES}

1. Carter PJ. Potent antibody therapeutics by design. Nat Rev Immunol. 2006; 6(5):343-357.

2. Schubert I, Stein C and Fey GH. Dual-Targeting for the Elimination of Cancer Cells with Increased Selectivity. Antibodies. 2012; 1(1):2-18.

3. Stein C, Schubert I and Fey GH. Natural Killer (NK)and T-Cell Engaging Antibody-Derived Therapeutics. Antibodies. 2012; 1(1):88-123.

4. Schwemmlein M, Peipp M, Barbin K, Saul D, Stockmeyer B, Repp R, Birkmann J, Oduncu F, Emmerich B and Fey GH. A CD33-specific single-chain immunotoxin mediates potent apoptosis of cultured human myeloid leukaemia cells. Br J Haematol. 2006; 133(2):141-151.

5. Schwemmlein M, Stieglmaier J, Kellner C, Peipp M, Saul D, Oduncu F, Emmerich B, Stockmeyer B, Lang P, Beck JD and Fey GH. A CD19-specific single-chain immunotoxin mediates potent apoptosis of B-lineage leukemic cells. Leukemia. 2007; 21(7):1405-1412.

6. Stieglmaier J, Bremer E, Kellner C, Liebig TM, ten Cate B, Peipp M, Schulze-Koops H, Pfeiffer M, Buhring HJ, Greil J, Oduncu F, Emmerich B, Fey GH and Helfrich W. Selective induction of apoptosis in leukemic B-lymphoid cells by a CD19-specific TRAIL fusion protein. Cancer Immunol Immunother. 2008; 57(2):233-246.

7. Hoffmann P, Hofmeister R, Brischwein K, Brandl C, Crommer S, Bargou R, Itin C, Prang N and Baeuerle PA. Serial killing of tumor cells by cytotoxic $\mathrm{T}$ cells redirected with a CD19-/CD3-bispecific single-chain antibody construct. Int J Cancer. 2005; 115(1):98-104.

8. Loffler A, Gruen M, Wuchter C, Schriever F, Kufer P, Dreier T, Hanakam F, Baeuerle PA, Bommert K, Karawajew L, Dorken B and Bargou RC. Efficient elimination of chronic lymphocytic leukaemia B cells by autologous T cells with a bispecific anti-CD19/anti-CD3 single-chain antibody construct. Leukemia. 2003; 17(5):900-909.

9. Kellner C, Bruenke J, Stieglmaier J, Schwemmlein M, Schwenkert M, Singer H, Mentz K, Peipp M, Lang P, Oduncu F, Stockmeyer B and Fey GH. A novel CD19directed recombinant bispecific antibody derivative with enhanced immune effector functions for human leukemic cells. J Immunother. 2008; 31(9):871-884.

10. Schubert I, Kellner C, Stein C, Kugler M, Schwenkert M, Saul D, Mentz K, Singer H, Stockmeyer B, Hillen W, Mackensen A and Fey GH. A single-chain triplebody with specificity for CD19 and CD33 mediates effective lysis of mixed lineage leukemia cells by dual targeting. MAbs. 2011; 3(1):21-30.
11. Schubert I, Kellner C, Stein C, Kugler M, Schwenkert M, Saul D, Stockmeyer B, Berens C, Oduncu FS, Mackensen A and Fey GH. A recombinant triplebody with specificity for CD19 and HLA-DR mediates preferential binding to antigen double-positive cells by dual-targeting. MAbs. 2012; 4(1):45-56.

12. Stein C, Kellner C, Kugler M, Reiff N, Mentz K, Schwenkert M, Stockmeyer B, Mackensen A and Fey GH. Novel conjugates of single-chain Fv antibody fragments specific for stem cell antigen CD123 mediate potent death of acute myeloid leukaemia cells. Br J Haematol. 2010; 148(6):879-889.

13. Arndt C, Feldmann A, von Bonin M, Cartellieri M, Ewen EM, Koristka S, Michalk I, Stamova S, Berndt N, Gocht A, Bornhauser M, Ehninger G, Schmitz M and Bachmann M. Costimulation improves the killing capability of $\mathrm{T}$ cells redirected to tumor cells expressing low levels of CD33: description of a novel modular targeting system. Leukemia. 2014; 28(1):59-69.

14. Thurber GM, Schmidt MM and Wittrup KD. Antibody tumor penetration: transport opposed by systemic and antigen-mediated clearance. Adv Drug Deliv Rev. 2008; 60(12):1421-1434.

15. Yokota T, Milenic DE, Whitlow M and Schlom J. Rapid tumor penetration of a single-chain $\mathrm{Fv}$ and comparison with other immunoglobulin forms. Cancer Res. 1992; 52(12):3402-3408.

16. McDonagh CF, Huhalov A, Harms BD, Adams S, Paragas V, Oyama S, Zhang B, Luus L, Overland R, Nguyen S, Gu J, Kohli N, Wallace M, Feldhaus MJ, Kudla AJ, Schoeberl B and et al. Antitumor activity of a novel bispecific antibody that targets the ErbB2/ErbB3 oncogenic unit and inhibits heregulin-induced activation of ErbB3. Mol Cancer Ther. 2012; 11(3):582-593.

17. Jung G, Grosse-Hovest L, Krammer PH and Rammensee HG. Target cell-restricted triggering of the CD95 (APO-1/Fas) death receptor with bispecific antibody fragments. Cancer Res. 2001; 61(5):1846-1848.

18. Hartmann F, Renner C, Jung W, Sahin U and Pfreundschuh M. Treatment of Hodgkin's disease with bispecific antibodies. Ann Oncol. 1996; 7(Suppl 4): $143-146$

19. Dreier T, Lorenczewski G, Brandl C, Hoffmann P, Syring U, Hanakam F, Kufer P, Riethmuller G, Bargou R and Baeuerle PA. Extremely potent, rapid and costimulation-independent cytotoxic T-cell response against lymphoma cells catalyzed by a single-chain bispecific antibody. Int J Cancer. 2002; 100(6):690-697.

20. Bargou R, Leo E, Zugmaier G, Klinger M, Goebeler M, Knop S, Noppeney R, Viardot A, Hess G, Schuler M, Einsele H, Brandl C, Wolf A, Kirchinger P, Klappers P, Schmidt $\mathrm{M}$ and et al. Tumor regression in cancer patients by very low doses of a T cell-engaging antibody. Science. 2008; 321(5891):974-977. 
21. Klinger M, Brandl C, Zugmaier G, Hijazi Y, Bargou RC, Topp MS, Gokbuget N, Neumann S, Goebeler M, Viardot A, Stelljes M, Bruggemann M, Hoelzer D, Degenhard E, Nagorsen D, Baeuerle PA and et al. Immunopharmacologic response of patients with B-lineage acute lymphoblastic leukemia to continuous infusion of $\mathrm{T}$ cell-engaging CD19/CD3-bispecific BiTE antibody blinatumomab. Blood. 2012; 119(26):6226-6233.

22. Topp MS, Kufer P, Gokbuget N, Goebeler M, Klinger M, Neumann S, Horst HA, Raff T, Viardot A, Schmid M, Stelljes M, Schaich M, Degenhard E, Kohne-Volland R, Bruggemann M, Ottmann $\mathrm{O}$ and et al. Targeted therapy with the T-cell-engaging antibody blinatumomab of chemotherapy-refractory minimal residual disease in B-lineage acute lymphoblastic leukemia patients results in high response rate and prolonged leukemia-free survival. J Clin Oncol. 2011; 29(18):2493-2498.

23. Handgretinger R, Zugmaier G, Henze G, Kreyenberg H, Lang $\mathrm{P}$ and von Stackelberg A. Complete remission after blinatumomab-induced donor T-cell activation in three pediatric patients with post-transplant relapsed acute lymphoblastic leukemia. Leukemia. 2011; 25(1): 181-184.

24. Topp MS, Gokbuget N, Zugmaier G, Degenhard E, Goebeler ME, Klinger M, Neumann SA, Horst HA, Raff T, Viardot A, Stelljes M, Schaich M, Kohne-Volland R, Bruggemann M, Ottmann OG, Burmeister $\mathrm{T}$ and et al. Long-term follow-up of hematologic relapse-free survival in a phase 2 study of blinatumomab in patients with MRD in B-lineage ALL. Blood. 2012; 120(26):5185-5187.

25. Aigner M, Feulner J, Schaffer S, Kischel R, Kufer P, Schneider K, Henn A, Rattel B, Friedrich M, Baeuerle PA, Mackensen A and Krause SW. T lymphocytes can be effectively recruited for ex vivo and in vivo lysis of AML blasts by a novel CD33/CD3-bispecific BiTE antibody construct. Leukemia. 2013; 27(5):1107-1115.

26. Krupka C, Kufer P, Kischel R, Zugmaier G, Bogeholz J, Kohnke T, Lichtenegger FS, Schneider S, Metzeler KH, Fiegl M, Spiekermann K, Baeuerle PA, Hiddemann W, Riethmuller G and Subklewe M. CD33 target validation and sustained depletion of AML blasts in long-term cultures by the bispecific T-cell-engaging antibody AMG 330. Blood. 2014; 123(3):356-365.

27. Brischwein K, Schlereth B, Guller B, Steiger C, Wolf A, Lutterbuese R, Offner S, Locher M, Urbig T, Raum $\mathrm{T}$, Kleindienst P, Wimberger P, Kimmig R, Fichtner I, Kufer P, Hofmeister R and et al. MT110: a novel bispecific single-chain antibody construct with high efficacy in eradicating established tumors. Mol Immunol. 2006; 43(8):1129-1143.

28. Haas C, Krinner E, Brischwein K, Hoffmann P, Lutterbuse R, Schlereth B, Kufer P and Baeuerle PA. Mode of cytotoxic action of T cell-engaging BiTE antibody MT110. Immunobiology. 2009; 214(6):441-453.
29. Offner S, Hofmeister R, Romaniuk A, Kufer $P$ and Baeuerle PA. Induction of regular cytolytic $\mathrm{T}$ cell synapses by bispecific single-chain antibody constructs on MHC class I-negative tumor cells. Mol Immunol. 2006; 43(6):763-771.

30. Osada T, Hsu D, Hammond S, Hobeika A, Devi G, Clay TM, Lyerly HK and Morse MA. Metastatic colorectal cancer cells from patients previously treated with chemotherapy are sensitive to T-cell killing mediated by CEA/ CD3-bispecific T-cell-engaging BiTE antibody. $\mathrm{Br} \mathrm{J}$ Cancer. 2010; 102(1):124-133.

31. Peng L, Oberst MD, Huang J, Brohawn P, Morehouse C, Lekstrom K, Baeuerle PA, Wu H, Yao Y, Coats SR, Dall'Acqua W, Damschroder M and Hammond SA. The CEA/CD3-bispecific antibody MEDI-565 (MT111) binds a nonlinear epitope in the full-length but not a short splice variant of CEA. PLoS One. 2012; 7(5):e36412.

32. Wortzel RD, Philipps C and Schreiber H. Multiple tumourspecific antigens expressed on a single tumour cell. Nature. 1983; 304(5922):165-167.

33. Schlereth B, Quadt C, Dreier T, Kufer P, Lorenczewski G, Prang N, Brandl C, Lippold S, Cobb K, Brasky K, Leo E, Bargou R, Murthy K and Baeuerle PA. T-cell activation and $\mathrm{B}-$ cell depletion in chimpanzees treated with a bispecific anti-CD19/anti-CD3 single-chain antibody construct. Cancer Immunol Immunother. 2006; 55(5):503-514.

34. Müller D and Kontermann R. Recombinant bispecific antibodies for cellular cancer immunotherapy. Curr Opin Mol Ther. 2007; 9(4):319-326.

35. Singer H, Kellner C, Lanig H, Aigner M, Stockmeyer B, Oduncu F, Schwemmlein M, Stein C, Mentz K, Mackensen A and Fey GH. Effective elimination of acute myeloid leukemic cells by recombinant bispecific antibody derivatives directed against CD33 and CD16. J Immunother. 2010; 33(6):599-608.

36. Kugler M, Stein C, Kellner C, Mentz K, Saul D, Schwenkert M, Schubert I, Singer H, Oduncu F, Stockmeyer B, Mackensen A and Fey GH. A recombinant trispecific single-chain $\mathrm{Fv}$ derivative directed against CD123 and CD33 mediates effective elimination of acute myeloid leukaemia cells by dual targeting. Br J Haematol. 2010; 150(5):574-586.

37. Guettinger Y, Barbin K, Peipp M, Bruenke J, Dechant M, Horner H, Thierschmidt D, Valerius T, Repp R, Fey GH and Stockmeyer B. A recombinant bispecific single-chain fragment variable specific for HLA class II and Fc alpha RI (CD89) recruits polymorphonuclear neutrophils for efficient lysis of malignant B lymphoid cells. J Immunol. 2010; 184(3):1210-1217.

38. Schubert I, Saul D, Nowecki S, Mackensen A, Fey GH and Oduncu F. A dual-targeting triplebody mediates preferential redirected lysis of antigen double-positive over singlepositive leukemic cells. MAbs. 2013; 6(1).

39. Kugler M, Stein C, Schwenkert M, Saul D, Vockentanz L, Huber T, Wetzel SK, Scholz O, Pluckthun A, Honegger A 
and Fey GH. Stabilization and humanization of a singlechain Fv antibody fragment specific for human lymphocyte antigen CD19 by designed point mutations and CDRgrafting onto a human framework. Protein Eng Des Sel. 2009; 22(3):135-147.

40. Brischwein K, Parr L, Pflanz S, Volkland J, Lumsden J, Klinger M, Locher M, Hammond SA, Kiener P, Kufer P, Schlereth B and Baeuerle PA. Strictly target cell-dependent activation of $\mathrm{T}$ cells by bispecific single-chain antibody constructs of the BiTE class. J Immunother. 2007; 30(8):798-807.

41. Gasteiger E, Hoogland C, Gattiker A, Duvaud S, Wilkins MR, Appel RD, Bairoch A, (2005) Protein Identification and Analysis Tools on the ExPASy Server. In: Walker JM, ed. The Proteomics Protocols Handbook: Humana Press), 571-607

42. Tallen G, Henze G, Von Stackelberg and A. Treatment of children and adolescents with relapsed ALL: therapy target long-term healing. Pharm Unserer Zeit. 2012; 41(3):214-221.

43. Restifo NP, Dudley ME and Rosenberg SA. Adoptive immunotherapy for cancer: harnessing the $\mathrm{T}$ cell response. Nat Rev Immunol. 2012; 12(4):269-281.

44. Baeuerle PA, Kufer P and Bargou R. BiTE: Teaching antibodies to engage T-cells for cancer therapy. Curr Opin Mol Ther. 2009; 11(1):22-30.

45. Wang XB, Zhao BF, Zhao Q, Piao JH, Liu J, Lin Q and Huang HL. A new recombinant single chain trispecific antibody recruits $\mathrm{T}$ lymphocytes to kill CEA (carcinoma embryonic antigen) positive tumor cells in vitro efficiently. J Biochem. 2004; 135(4):555-565.

46. Liu J, Zhao Q, Zhao B, Cheng J, Wang X, Song L, Zhong Z, Lin $Q$ and Huang H. A new format of single chain trispecific antibody with diminished molecular size efficiently induces ovarian tumor cell killing. Biotechnol Lett. 2005; 27(22):1821-1827.

47. Harms BD, Kearns JD, Iadevaia S and Lugovskoy AA. Understanding the role of cross-arm binding efficiency in the activity of monoclonal and multispecific therapeutic antibodies. Methods. 2014; 65(1):95-104.

48. Lillemeier BF, Pfeiffer JR, Surviladze Z, Wilson BS and Davis MM. Plasma membrane-associated proteins are clustered into islands attached to the cytoskeleton. Proc Natl Acad Sci U S A. 2006; 103(50):18992-18997.

49. Lillemeier BF, Mortelmaier MA, Forstner MB, Huppa JB, Groves JT and Davis MM. TCR and Lat are expressed on separate protein islands on $\mathrm{T}$ cell membranes and concatenate during activation. Nat Immunol. 2010; 11(1):90-96.

50. Greil J, Gramatzki M, Burger R, Marschalek R, Peltner M, Trautmann U, Hansen-Hagge TE, Bartram CR, Fey GH, Stehr $\mathrm{K}$ and et al. The acute lymphoblastic leukaemia cell line SEM with $\mathrm{t}(4 ; 11)$ chromosomal rearrangement is biphenotypic and responsive to interleukin-7. $\mathrm{Br} \mathrm{J}$ Haematol. 1994; 86(2):275-283.

51. Drexler HG. 2010; Guide to Leukemia-Lymphoma Cell Lines. (Braunschweig).

52. Alici E, Sutlu T, Bjorkstrand B, Gilljam M, Stellan B, Nahi H, Quezada HC, Gahrton G, Ljunggren HG and Dilber MS. Autologous antitumor activity by NK cells expanded from myeloma patients using GMP-compliant components. Blood. 2008; 111(6):3155-3162.

53. Benedict CA, MacKrell AJ and Anderson WF. Determination of the binding affinity of an anti-CD34 single-chain antibody using a novel, flow cytometry based assay. J Immunol Methods. 1997; 201(2):223-231.

54. Braciak TA, Wildenhain S, Roskopf CC, Schubert IA, Fey GH, Jacob U, Hopfner KP and Oduncu FS. NK cells from an AML patient have recovered in remission and reached comparable cytolytic activity to that of a healthy monozygotic twin mediated by the single-chain triplebody SPM-2. J Transl Med. 2013; 11(1):289.

55. Olejniczak SH, Stewart CC, Donohue K and Czuczman MS. A quantitative exploration of surface antigen expression in common B-cell malignancies using flow cytometry. Immunol Invest. 2006; 35(1):93-114.

56. Fauriat C, Andersson S, Bjorklund AT, Carlsten M, Schaffer M, Bjorkstrom NK, Baumann BC, Michaelsson J, Ljunggren HG and Malmberg KJ. Estimation of the size of the alloreactive NK cell repertoire: studies in individuals homozygous for the group A KIR haplotype. J Immunol. 2008; 181(9):6010-6019. 